\title{
Robert Koch and the Pressures of Scientific Research: Tuberculosis and Tuberculin
}

\author{
CHRISTOPH GRADMANN*
}

\section{Introduction}

Robert Koch's identification of the tuberculosis pathogen in 1882 is held to be his greatest scientific achievement. In the eyes of his friend and colleague, Friedrich Löffler, the discovery was a "world-shaking event" which resulted in both instant and everlasting fame, turning Koch "overnight into the most successful and outstanding researcher of all times". ${ }^{1}$ Paul Ehrlich, remembering Koch's presentation in Emil du Bois Reymond's Institute for Physiology in Berlin on 24 March 1882, called it "my single greatest scientific experience". ${ }^{2}$ The sensational character of Koch's achievement, which is noted in Löffler's and Ehrlich's retrospective statements, seems to have been obvious to contemporaries of the event. ${ }^{3}$ Albert Johne, writing a history of tuberculosis in 1883, found that history had, in a way, come to an end: "resulting from the latest of Koch's publications, the pathogenic aspects of the tubercle question are settled at large" ${ }^{4}$ Koch himself profited from the overwhelming reception by being promoted to the rank of a senior executive officer, Geheimer Regierungsrath, in June 1882. ${ }^{5}$ March 24, 1882 thus came to stand for two things: Koch's breakthrough to world fame and a sort of doomsday for tuberculosis. Not surprisingly, the event was held in similar esteem by later biographers: Bernhard Möllers in 1950 called it the "greatest and most important success of his life", ${ }^{6}$ and Thomas Brock, Koch's most recent biographer, assessed the discovery of the tubercle bacillus as the first of two steps on Koch's road to fame in the early 1880s. In conjunction with the 1883-84

\footnotetext{
* Christoph Gradmann, Dr Phil., Institut für Geschichte der Medizin, Ruprecht-KarlsUniversität Heidelberg, INF 327, 69120 Heidelberg, Germany.

I started to work on this paper at the Max Planck Institute for the History of Science in Berlin and would like to express gratitude to Hans-Jörg Rheinberger, Michael Hagner and the other members of Dept. III. Wolfgang Eckart, Lily Kay, Andrew Mendelsohn, Thomas Schlich and Ton van Helvoort supplied criticisms on various versions of the text. Mark Harrison took the trouble to go through the English. All translations are by the author unless otherwise stated.

${ }^{1}$ Friedrich Löffler, 'Zum 25jährigen Gedenktage der Entdeckung des
}

Tuberkelbazillus', Dtsch. med. Wochenschr., 1907, 33: 449-51, 489-95, on p. 449.

${ }^{2}$ Ehrlich in Frankfurter Zeitung, 2.6.1910, repr. in Bernhard Möllers, Robert Koch. Persönlichkeit und Lebenswerk 1843-1910, Hanover, Schmorl und von Seefeld, 1950, p. 133.

${ }^{3}$ On the surroundings of Koch's speech and its reception, see Thomas Schlich, 'Ein Symbol medizinischer Fortschrittshoffnung. Robert Koch entdeckt den Erreger der Tuberkulose', in H Schott (ed.), Meilensteine der Medizin, Düsseldorf, Harenberg, 1996, pp. 368-74.

${ }^{4}$ Albert Johne, Die Geschichte der Tuberkulose mit besonderer Berücksichtigung der Tuberkulose des Rindes und die sich daraus ergebenden medicinal- $u$. veterinärpolizeilichen Consequenzen, Leipzig, F C W Vogel, 1883, p. 4.

${ }^{5}$ Möllers, op. cit. note 2 above, p. 133.

${ }^{6}$ Ibid., 132. 


\section{Christoph Gradmann}

cholera expedition, which made Koch a hero for the public, the tubercle bacillus indicated his breakthrough in the scientific world. ${ }^{7}$

However, the discovery of the tubercle bacillus was not the completion of Koch's work on the disease, but rather the beginning of a lifelong and intensive study. Almost until Koch's death in 1910, we find numerous papers, lectures, and reports on the issue. ${ }^{8}$ It should be noted that the triumphant discovery of 1882 was followed by a succession of failures: first of all, the failed attempt to present tuberculin as a remedy against tuberculosis in 1890-91, which severely damaged Koch's reputation. The year 1897 saw a subsequent attempt with an improved tuberculin, which turned out to be just as ineffective as the original substance. Finally, in 1902, Koch made his ill-fated statement of the non-identity of human and bovine tuberculosis. ${ }^{9}$

This article aims to investigate a path which has not received its due attention: one that led from the initial work on tuberculosis between 1882 and 1884 to the tuberculin disaster of 1890-91. None of the treatments of tuberculin explores links between the earlier work on the pathogen and the subsequent failure of the cure; at least, none goes beyond mere rhetoric-i.e. the reputation of the cure was based on the fame of the discovery. ${ }^{10}$ The two standard biographies by Möllers and Brock offer a combined assessment which is most clearly developed by the latter. ${ }^{11}$ The

\footnotetext{
${ }^{7}$ Thomas D Brock, Robert Koch: a life in medicine and bacteriology, Madison, Science Tech Publishers, 1988, pp. 117-68.

${ }^{8}$ Koch published an epidemiological paper on the issue in 1910: Robert Koch, 'Epidemiologie der Tuberkulose', in Gesammelte Werke von Robert Koch, ed. J Schwalbe, Leipzig, Georg Thieme, 1912 [1910], vol. 1, pp. 636-49. In late 1909 Koch reported his occupation with extensive experimental studies on tuberculosis to Wilhelm Kolle: Koch to Kolle, Berlin 26.11.1909, Staatsbibliothek Preussischer Kulturbesitz, Berlin (hereafter SBPK), Slg Darmst., 3 b 1882 (2) Koch, Robert,Bl.41/42.

${ }^{9}$ See Barbara Gutmann Rosenkrantz, 'The trouble with bovine tuberculosis', Bull. Hist. Med., 1985, 59: 155-75.

${ }^{10}$ Relevant treatments of the tuberculin affair: Brock, op. cit., note 7 above, pp. 195-213; Barbara Elkeles, 'Der “Tuberkulinrausch" von 1890', Dtsch. med. Wochenschr., 1990, 115: 1729-32; idem, Der moralische Diskurs über das medizinische Menschenexperiment im 19. Jahrhundert, Stuttgart and Jena, Gustav Fischer, 1996, pp. 131-151; Gerhard Eschenhagen, 'Das Hygiene-Institut der Berliner Universität unter der Leitung Robert Kochs 1883-1891', Diss. Med., Berlin (HU), 1983, pp. 128-40; Thomas Gorsboth and Bernd Wagner, 'Die Unmöglichkeit der Therapie. Am Beispiel der Tuberkulose', Kursbuch (Die Seuche),1988, 94: 123-45; Christoph Gradmann, 'Money and
}

microbes: Robert Koch, tuberculin and the foundation of the Institute for Infectious Diseases in Berlin in 1891', Hist. Philos. Life Sci., 2000, 22: 51-71; Bernhard Opitz and Herwarth Horn, 'Die Tuberkulinaffäre. Neue Medizinhistorische Untersuchungen zum Kochschen Heilverfahren', $Z$. gesamte Hygiene, 1984, 30: 731-4. If any links are claimed, they are restricted to the rhetorical level, such as when Barbara Elkeles analyses how the reputation of tuberculin in the public was largely based on the fame which Koch had acquired in his previous work.

${ }^{11}$ The relevant Koch biographies are: Brock, op. cit., note 7 above; Bruno Heymann, Robert Koch. I. Teil 1843-1882, Leipzig, Akademische Verlagsanstalt, 1932; idem, Robert Koch Biographie II. Teil, ed. G Henneberg, K Janitschke, K Stürzbecher, and R Winau, Berlin, Robert Koch-Institut, 1997; Möllers, op. cit., note 2 above. A bibliographic overview of literature on Koch up to the early 1980s can be found in Ehrentraut Holz, Robert Koch (1843-1910). Auswahlbibliographie, Berlin, HUBibliothek, 1981. For more recent literature, see Christoph Gradmann, 'Koch, Robert', in Encyclopedia of the life sciences, London, Macmillan, 2000. The best introduction to Koch's scientific work is Claude E Dolman, 'Koch, Heinrich Hermann Robert', in Dictionary of Scientific Biography, 16 vols, New York, Charles Scribner's Sons, 1973, vol. 7, pp. 420-35. 


\section{Robert Koch and the Pressures of Scientific Research}

story of tuberculin is portrayed as a unique disaster on the one hand, while, on the other, Koch's ideas on the issue are explicitly related to future work in immunology conducted by others. ${ }^{12}$

This paper, instead, makes the following claim: that Koch's work on tuberculin is best understood in connection with his previous and tremendously successful work on tuberculosis. The tuberculin disaster is much more than an "error" and should instead be assessed in the context of a research programme on tuberculosis which produced spectacular results in the early 1880 s and dramatically failed with the supposed cure of 1890/91. The conception of Koch's cure for tuberculosis in 1890 was closely connected to the ideas on the disease he had developed in the early 1880 s, and the problems of tuberculin are in fact problems of Koch's understanding of tuberculosis at large. Even if the tuberculin reaction became incorporated into the history of immunology later on, ${ }^{13}$ it is historically inaccurate to see Koch's work as part of such research. Koch did not move in the direction of cellular immunology or even in that of the "discovery of bacterial allergy". ${ }^{14}$ Instead he explained the tuberculin reaction without touching any question that can be related to concepts of immunity. The purpose of this paper is thus to reconstruct Koch's conception of tuberculosis as an infectious disease and to analyse this conception by comparing it to what he thought was a cure for it.

The approach chosen is biographical in a broad sense of the term: the analysis includes biographical questions, most notably whether the notion of (self-)deception provides a useful tool for an understanding of Koch's road to tuberculin and his conduct in the tuberculin affair. Does his personal, professional, and intellectual situation in the late 1880 s-i.e. the years between the discovery of the pathogen and the presentation of the cure-shed some light on the hazardous enterprise that tuberculin certainly was? ${ }^{15}$ Secondly, the tools of research such as bacteria, staining and culturing techniques, laboratory animals, and the image of tuberculosis which was based on their use, will be examined. Finally, Koch's work will be placed within larger historical contexts. These include professional competition, most notably with Pasteur and his school, and the issue of how Koch's work on bacterial etiology can be placed in the history of contemporary speculative pathology, in particular with regard to changing concepts of infectious diseases.

\footnotetext{
${ }^{12}$ Brock, who clearly states the failure of tuberculin as a remedy, assesses Koch's announcement of tuberculin in August 1890 as the first ever published paper on cellular immunology, a field which, however, proved almost impenetrable for Koch due to shortcomings of contemporary laboratory methodology and technology (Brock, op. cit., note 7 above, pp. 196-8). Cf. Möllers, op. cit., note 2 above, pp. 591-3.
}

\footnotetext{
${ }^{13}$ Arthur Silverstein, A history of immunology, San Diego, Academic Press, 1989, ch. 9.

${ }^{14}$ William Foster, $A$ history of medical bacteriology and microbiology, London, William Heinemann Medical Books, 1970, p. 62.

${ }^{15}$ Gerald Geison has analysed Pasteur's research on anthrax and rabies from a comparable perspective: Gerald L Geison, The private science of Louis Pasteur, Princeton University Press, 1995, pp. 145-256.
} 


\section{Christoph Gradmann}

\section{The Bacterial Etiology of Tuberculosis}

The announcement of the discovery of the tubercle bacillus on 24 March opened a series of four papers by Koch on the issue. The publication of the famous lecture itself ${ }^{16}$ was followed by a similar but shorter paper in summer $1882,{ }^{17}$ a short review of "publications directed against the significance of the tubercle bacilli" in early $1883^{18}$ and finally in 1884 by the monumental paper 'On the etiology of tuberculosis', in which he gave a detailed account and discussion of his approach. ${ }^{19}$ But what exactly was discovered, how was this done, and why should it be considered a major discovery? Some information on the object of inquiry and Koch's path of investigation will help to clarify this point.

First, the object of research itself offered enough potential prominence for any researcher. Koch had started his career as a bacteriologist by investigating anthrax, an animal disease that rarely attacked humans. Later, when working on wound infections, he had investigated phenomena whose infectiousness seemed obvious. With the tubercle bacillus, he was entering a terrain that was both prominent and scientifically contested in a peculiar way: tuberculosis, the "captain of all the men of death", was one of the epidemiologically dominant diseases of its age, mostly appearing as pulmonary tuberculosis or phthisis. Its more or less stable endemic presence, and the often prolonged character of the pathological process, further increased the reputation of "the white plague" ${ }^{20}$ Not surprisingly, the disease had been subjected to intensive and controversial research for quite some time. ${ }^{21}$ However, without a bacterial etiology yet being established, not even the connectedness of all those pathological phenomena which came to be included under "tuberculosis" by the bacteriological diagnosis was established at that time. There was instead a group

\footnotetext{
${ }^{16}$ Robert Koch, 'Die Ätiologie der Tuberkulose' (1882), in Gesammelte Werke, op. cit., note 8 above, vol. 1 , pp. $428-45$.

${ }^{17}$ Idem, 'Über die Ätiologie der Tuberkulose' (1882), in Gesammelte Werke, op. cit., note 8 above, vol. 1, pp. 446-53.

${ }^{18}$ Idem, 'Kritische Besprechung der gegen die Bedeutung der Tuberkelbazillen gerichteten Publikationen', in Gesammelte Werke, op. cit., note 8 above, vol. 1, pp. 454-66.

${ }^{19}$ Idem, 'Die Ätiologie der Tuberkulose' (1884), in Gesammelte Werke, op. cit., note 8 above, vol. 1, pp. 467-565.

${ }^{20}$ The literature on the history of tuberculosis, namely on the social history and epidemiology of the disease, is vast. As an introduction, see Barbara Gutmann Rosenkrantz, From consumption to tuberculosis: a documentary history, New York and London, Garland, 1994. A standard history of tuberculosis is: René Jules Dubos, Jean Dubos and Gutmann Rosenkrantz (eds), The white plague: tuberculosis, man, and society, New Brunswick, Rutgers University Press, 1987. For a more recent assessment, see David S Barnes, The making of a social disease:
}

tuberculosis in nineteenth-century France, Berkeley, University of California Press, 1995. A good indication for the reputation of consumption is its massive presence in contemporary fiction: Dietrich von Engelhardt, Medizin in der Literatur der Neuzeit, Bd.I. Darstellung und Deutung, Hürtgenwald, Guido Pressler, 1991, pp. 73-89.

${ }^{21}$ On the history of tuberculosis-conceptions, see Richard Bochalli, Die Entwicklung der Tuberkuloseforschung in der Zeit von 1878-1958. Rückblick eines deutschen Tuberkulosearztes, Stuttgart, Georg Thieme, 1958; Lester King, Medical thinking: a historical preface, Princeton University Press, 1982; J Arthur Myers, 'Development of knowledge of unity of tuberculosis and of the portals of entry of tubercule bacilli', J. Hist. Med. Allied Sci., 1974, 29: 213-28. Cf. G Seiffert, 'Die Tuberkulose als übertragbare Krankheit und ihre Bekämpfung vor Robert Koch', Münch. Med. Wochenschr., 1932, 79: 501-6. An older and valuable history of research on tuberculosis up to Koch is: August Predöhl, Die Geschichte der Tuberkulose, Wiesbaden, Dr. Martin Sändig OHG, 1966 repr. [1888]. 


\section{Robert Koch and the Pressures of Scientific Research}

of suspected tuberculous diseases, which were defined in relation to protean clinical symptoms and findings of pathological anatomy. The French clinician Théophile Laennec had in 1819 stated the unity of phthisis, miliary tuberculosis, caseous pneumonia, lupus, etc. as tuberculosis, and had based his claim on the characteristic granules, the tubercles. ${ }^{22}$ German physicians, however, took a different stance from the mid-nineteenth century onwards. Following Virchow's demonstration of the microscopical structure of the tubercles, formerly tuberculous phenomena became divided into non-specific inflammations and a caseous metamorphosis which could follow. Tuberculosis in various organs was no longer thought to result from a general disease, but from the tuberculous transformation of other pathological processes. Contemporaries thus preferred to refer to the epidemiologically dominant phthisis and to discuss its relation to other diseases. ${ }^{23}$

The case with the suspected causes was similar: factors other than infection, such as disposition, age, environment, and heredity, were considered to be important. A relation to cancer had long been thought to play an important role. None of these factors was considered a decisive, i.e. necessary, cause of the disease, transformation was thought more significant than causation. ${ }^{24}$ Felix Niemeyer, in 1863, criticized the term tuberculosis, because it confused creation and transformation of pathological processes. In his view, the latter was central, e.g. when cancer became tuberculous. ${ }^{25}$

Koch could relate, however, to a well established tradition of research which attempted to prove the infectiousness of the disease. Philipp Friederich Hermann Klenke in $1843,{ }^{26}$ and Jean Antoine Villemin in $1865,{ }^{27}$ had stated that the disease could be transferred via tuberculous tissue and was thus to be regarded as infectious. In 1877, Edwin Klebs had put forward the thesis that the suspected virus of tuberculosis should be regarded as a bacterium. ${ }^{28}$ Breslau University, in particular, a place from which Koch had received support in the early stages of his career, ${ }^{29}$ hosted a number of physicians doing laboratory studies on the issue. Carl Weigert had, in 1879, proposed that the conflation of various tuberculous phenomena into a single infectious disease should be based on etiology instead of clinical appearance or pathological anatomy. ${ }^{30}$ Julius Cohnheim and Carl Salomonsen had confirmed

\footnotetext{
${ }^{22} \mathrm{King}$, op. cit., note 21 above, pp. $34-5$. Cf. Jacalyn Duffin, To see with a better eye: $a$ life of R. T. H. Laennec, Princeton University Press, 1998, chs 7 and 8.

${ }^{23}$ Knud Faber, Nosography: the evolution of clinical medicine in modern times, New York, Paul B Hoeber, 1930, pp. 76-8.

${ }^{24} \mathrm{~K}$ Codell Carter, 'Koch's postulates in relation to the work of Jacob Henle and Edwin Klebs', Med. Hist., 1985, 29: 353-75, has pointed to the circumstance that the idea of etiology itself was not a very developed one (p. 371). E.g., for Koch's teacher Henle the infectiousness of a disease did not necessarily imply the existence of a pathogen.

${ }^{25}$ Felix Niemeyer, Lehrbuch der speziellen Pathologie und Therapie mit besonderer Rücksicht
}

auf Physiologie und pathologische Anatomie, 2 vols, Berlin, August Hirschwald, 1863, vol. 1, p. 171.

${ }^{26}$ Predöhl, op. cit., note 21 above, p. 169.

${ }^{27}$ Ibid, pp. 171-5.

${ }^{28}$ Ibid, p. 331.

${ }^{29}$ On the support of Koch's anthrax studies by Cohn and other Breslau physicians, see Heymann, Robert Koch. I, op. cit., note 11 above, pp. 137-62.

${ }^{30}$ Carl Weigert, 'Zur Lehre von der Tuberculose und von verwandten Erkrankungen', Archiv für pathologische Anatomie und Physiologie und für klinische Medizin, 1879, 77: 269-98. 


\section{Christoph Gradmann}

Villemin's results and had proposed relying on animal experimentation and animal pathology as tools of research. ${ }^{31}$

In this situation, the successful linking of tuberculosis to a bacterial agent could be expected to have dramatic effects: in the complicated array of the various supposed tuberculous diseases the introduction of a single necessary cause would mean a radical turn-even if the notion of the disease being unified and infectious was not new in itself. Adding to the redrawing of the boundaries of tuberculosis, it would mean the first clear bacterial etiology of a major human infectious disease and could thus be expected to serve as a blueprint for further research into others, accelerating a gradual shift from clinical to bacteriological definitions of diseases. ${ }^{32} \mathrm{~A}$ dramatic impression on the scientific and wider public was equally to be expected, since the concept of bacteria as necessary causes raised hopes of finding a method for control.

Koch's task in this situation was clear: to link previous research on the disease to the methods of bacteriological proof he had developed. Consequently, he portrayed his endeavour as an application of a developed technology and well-tried methods upon a new object, where, in principle, "the same procedure of investigation, which had proved to be effective on other occasions, was to be followed". ${ }^{33}$ The speed with which Koch undertook his investigations is indeed impressive-even if one takes into account that he was no longer the lone country physician he had been earlier, but the leader of a mushrooming team at the Imperial Health Office in Berlin. ${ }^{34}$ Prior to working on the tubercle bacillus, Koch and his group had already invented basic and revolutionary techniques, most notably pure cultures grown on fixed culture media. A mere eight months separated the beginning of investigations in August 1881 and the famous lecture of March $1882 .{ }^{35}$ Of course, Koch emphasized new problems that arose. These, however, were blamed on the object of inquiry rather than "proven" methods. Thus the frightening size of the object of investigation was contrasted with the extraordinary difficulties that arose while researching it. ${ }^{36}$ In his subsequent account, Koch described how, particularly while identifying the pathogen, but also while cultivating it and in animal experimentation, he had encountered peculiar problems for which he found appropriate solutions.

The micro-organism turned out to be much smaller than any other already known; indeed it seemed almost invisible without special preparations. Koch had initially,

\footnotetext{
${ }^{31}$ Julius Cohnheim, Die Tuberkulose vom Standpunkte der Infektionslehre, 2nd ed., Leipzig, Edelmann, 1881. Cf. Wilhelm Doerr, 'Cohnheims Entzündungslehre und die aktuelle Debatte', Zentralblatt für allgemeine Pathologie und pathologische Anatomie, 1985, 130: 299-306.

${ }^{32} \mathrm{Cf}$., for the example of plague, Andrew Cunningham, 'Transforming plague. The laboratory and the identity of infectious disease', in A Cunningham and P Williams (eds), The laboratory revolution in medicine, Cambridge University Press, 1992, pp. 209-24.

${ }^{33}$ Koch, 'Die Ätiologie der Tuberkulose' (1884), op. cit., note 19 above, p. 469.

${ }^{34}$ On the history of the Imperial Health Office, see Reichsgesundheitsamt (ed.), Das
}

Reichsgesundheitsamt 1876-1926. Festschrift, hg. vom Reichsgesundheitsamt aus Anlaß seines fünzigjährigen Bestehen, Berlin, J Springer, 1926; Gerhard A Ritter, Großforschung und Staat in Deutschland. Ein historischer Überblick, Munich, Beck, 1992, pp. 19-20.

${ }^{35}$ Möllers, op. cit., note 2 above, p. 535

${ }^{36}$ For example, when Koch claimed that "the methods employed to proof pathogenic microorganisms had failed in face of this disease" (Koch, 'Die Ätiologie der Tuberkulose' (1882), op. cit., note 16 above, p. 427), or remarked that "[d]uring my investigations I initially applied the established methods and reached no elucidation on the nature of the disease" (ibid, p. 429). 


\section{Robert Koch and the Pressures of Scientific Research}

in his work on anthrax, studied bacteria without the application of specific staining methods. Later staining techniques, which Koch had learned from Carl Weigert and others, had served to distinguish bacteria from organic tissue and to prepare his findings for micro-photography ${ }^{37}$ Investigating tuberculous matter posed an entirely new problem, since initially any "efforts to find bacteria or other micro-organisms in these preparations remained without success" ${ }^{38}$ Only after the application of alkaline methylene blue did something become visible at all and "very fine rod-like structures showed up". ${ }^{39}$ The next task was to distinguish those rods from the neighbouring tissues. This was achieved with the help of a new kind of staining technique: if the preparation was discoloured using a second brown dye, Vesuvin, this affected only the tissue. The result was blue rods surrounded by brown tissue. Another advantage of double-staining was that it applied only to tubercle bacilli and thus made them distinguishable from all other known bacteria. ${ }^{40}$ This technique, soon to be much improved by Paul Ehrlich, enabled Koch to find the rods constantly in tuberculous tissues and to describe their typical arrangement in "usually dense and often bundle-like arranged small groups". ${ }^{41}$

That Koch had to use staining in order to make his bacteria visible in the first place not only proved his "strong faith" 42 in the parasitic nature of tuberculosis and the existence of a pathogen, it also freed him from the task of comparing his findings with anything other researchers had seen so far. Since nobody had applied a comparable staining technique and the bacteria remained invisible without such a device, these researchers had all seen something else:

Upon the regularity with which tubercle bacilli can be found, it seems curious that nobody has seen them previously. This, however, can be explained by the exceeding smallness of these structures and their usually small numbers ... for this simple reason their existence escapes even the most attentive observer without their peculiar reaction to staining. ${ }^{43}$

It seems, however, that the Königsberg physician Paul Baumgarten had identified the micro-organisms almost simultaneously and had succeeded without staining.

\footnotetext{
${ }^{37}$ Robert Koch, 'Verfahren zur Untersuchung, zum Konservieren und Photographieren der Bakterien' (1877), in Gesammelte Werke, op. cit., note 8 above, vol. 1, pp. 27-50. Cf. William Bulloch, The history of bacteriology, London, Oxford University Press, 1960 (1938), pp. 213-17; Heymann, Robert Koch. I, op. cit., note 11 above, p. 168. On the history of bacteriological bacterial staining, see George Clark and Frederick $\mathrm{H}$ Kasten, History of staining, 3rd ed., Baltimore, Williams \& Wilkins, 1983, pp. 91-101; on the use of aniline dyes, Brian Bracegirdle, $A$ history of microtechnique, New York, Cornell University Press 1978, pp. 70-4; on Ehrlich's development of staining techniques, Anthony S Travis, 'Science as receptor of technology: Paul Ehrlich and the synthetic dyestuffs', Science in Context,1989, 3: 383-408. Cf. Thomas Schlich, 'Repräsentationen von Krankheitserregern. Wie Robert Koch Bakterien als Krankheitserreger dargestellt hat',
}

in H-J Rheinberger, M Hagner and B WahrigSchmidt (eds), Räume des Wissens.

Repräsentation, Codierung, Spur, Berlin, Akademie Verlag, 1997, pp. 165-90.

${ }^{38}$ Koch, 'Die Ätiologie der Tuberkulose' (1884), op. cit., note 19 above, p. 472.

${ }^{39}$ Ibid. In his lecture of summer 1882 Koch gave a somewhat different account claiming that the bacteria could be observed without staining if one had-by staining - convinced oneself earlier on of their existence (Koch, 'Über die Ätiologie der Tuberkulose' (1882), op. cit., note 17 above, p. 448).

${ }^{40}$ Koch, 'Die Ätiologie der Tuberkulose'

(1882), op. cit., note 16 above, p. 429.

${ }^{41}$ Ibid., p. 430.

${ }^{42}$ Brock, op. cit., note 7 above, p. 119.

${ }^{43}$ Koch, 'Die Ätiologie der Tuberkulose' (1882), op. cit., note 16 above, pp. 432-3. 


\section{Christoph Gradmann}

Baumgarten had observed similar structures under his microscope and described their relation to the pathological alterations. He even discussed his findings, which were presented prior to Koch's lecture and came to be published later in 1882, in relation to Koch's. ${ }^{44}$ Since it can be shown that Koch had by no means finished his experiments in March 1882 - indeed they continued well into 1883-one could be tempted to see his announcement of March 1882 as an attempt not to cede priority to Baumgarten. ${ }^{45}$ However, it needs to be emphasized that Baumgarten restricted his work to the identification of the bacterium whereas Koch proceeded to culturing and inoculation.

Related to this is the surprising fact that Koch did not say a word about his failed attempts to acquire photographic pictures of his findings. Koch had not long before invented and sung the praises of micro-photography. He had characterized it as the one and only "purely objective conception free from any partiality" 46 and contrasted it with biased and subjective drawings. That he had to publish his findings as drawings is not even discussed in the text. ${ }^{47}$ From Löffler's account of Koch's discovery we learn that double staining was indeed developed while trying to get photographs of the bacteria that had been stained with methylene blue..$^{48}$

All in all, double-staining went beyond a mere technical invention. Far more than the micro-organisms Koch had worked on previously, the tubercle bacteria were products of the investigative process. Minor mistakes in the application of the various dyes could, for example, produce blue staining of totally different, non-bacterial, parts of the preparations. ${ }^{49}$

In this context, it is of some importance that Koch wrote in his 1884 paper about "spores", that is to say resistant and durable forms of the tubercle bacterium. The demonstration of such a stage in the life cycle of bacteria had been crucial in establishing the stability of bacterial species. In the early 1870s, Koch's teacher Ferdinand Julius Cohn had done most of the work on the issue. In Koch's own work on anthrax, the demonstration of a spore stage had been a central step. It completed the life cycle of the bacterium and accounted for its survival under unfavourable conditions. ${ }^{50}$ Koch attributed similar properties to his tuberculosis

\footnotetext{
${ }^{44}$ Paul Baumgarten, 'Tuberkelbakterien', Centralblatt für die medizinischen Wissenschaften, 1882, 20: 257-9. However, Baumgarten had brightened up his preparations using sodium hydroxide and potasium hydroxide. Cf. Brock, op. cit., note 7 above, p. 133. Cf. Predöhl, op. cit., note 21 above, pp. 347-9, who emphasizes the simultaneous identification of the pathogen and gives a detailed account of Baumgarten's research.

${ }^{45}$ Archives of the Robert-Koch-Institut/Berlin, Folder 'Versch. Tuberkulose-S. 1881/82'.

${ }^{46}$ Robert Koch, 'Zur Untersuchung von pathogenen Mikroorganismen', in Gesammelte Werke, op. cit, note 8 above, vol. 1, pp. 112-63, on p. 122. Cf. Thomas Schlich, "Wichtiger als der Gegenstand selbst"-Die Bedeutung des
}

fotografischen Bildes in der Begründung der bakteriologischen Krankheitsauffassung durch Robert Koch', in M Dinges and T Schlich (eds), Neue Wege in der Seuchengeschichte, Stuttgart, Franz Steiner, 1995, pp. 143-74.

${ }^{47}$ See Koch, 'Die Âtiologie der Tuberkulose' (1884), op. cit., note 19 above, p. 484, where Koch gives the exact sizes of the bacteria and compares them with others, of which he had acquired photographs.

${ }^{48}$ Löffler, op. cit., note 1 above, p. 451.

${ }^{49}$ Koch, 'Die Ätiologie der Tuberkulose' (1884), op. cit., note 19 above, p. 479.

${ }^{50}$ Friedrich Löffler, Vorlesungen über die geschichtliche Entwicklung der Lehre von den Bakterien, Leipzig, Vogel, 1887, pp. 164-7. 


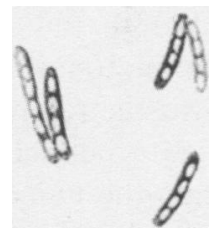

Figure 1: Koch's spores. The white globules inside the bacteria are the spores. This drawing was given in a magnification that exceeded the ones chosen for any other illustration in Koch's text. From Koch's 'Die Ätiologie der Tuberkulose' (1884), in Gesammelte Werke von Robert Koch, ed. J Schwalbe, Leipzig, George Thieme, 1912, table 29, fig. 47.

spores, describing them as a state of permanence (Dauerform) "necessary for the preservation of the species", ${ }^{1}$ and attributed the sustained virulence of sputum to the presence of such spores in it. ${ }^{52}$ However, Koch's tuberculosis spores seemed to ceased to exist later on $^{53}$ and had some quite peculiar properties. They were resistant to staining and in a way invisible: "since there are up until now no means of staining the spores of the tubercle bacilli in any way, their presence after the bacteria have disappeared can only be told from the contagious qualities of the caseous mass in which they are embedded". ${ }^{54}$ Koch supplied a non-instructive picture of these spores, describing them as "oval in shape" and lined up in numbers of two to four inside a bacterium. ${ }^{55}$ Given Koch's contradictory statements, it may suffice for the moment to note the important role these spores played in his line of argument. They made it possible to assert the existence of bacteria in places where their presence could not be shown with certainty under the microscope, such as the caseous mass inside the tubercles. ${ }^{56}$

Koch's insistence that his staining methods were "proven" techniques served to play down the quite unique problems that arose in the preparation of tubercle

\footnotetext{
${ }^{51}$ Koch, 'Die Ätiologie der Tuberkulose' (1884), op. cit., note 19 above, p. 551.

52 Ibid, p. 554.

${ }^{53}$ For Koch's pupil Carl Fränkel the question whether spores existed was open: Carl Fränkel, Grundriß der Bakterienkunde, 3rd ed., Berlin, Hirschwald, 1890 , p. 308. In Kolle and Wassermann's Handbuch der pathogenen Mikroorganismen spores are discussed with reservation and denied: Georg Cornet and Arthur Meyer, 'Tuberkulose', in W Kolle and A Wassermann (eds), Handbuch der pathogenen Mikroorganismen, 6 vols, Jena, Gustav Fischer,
}

1903, vol. 2, pp. 78-177, on p. 81. Cf. Dolman, op. cit., note 11 above, p. 423.

${ }^{54}$ Koch, 'Die Ätiologie der Tuberkulose' (1884), op. cit., note 19 above, p. 485.

${ }^{55}$ For the description of the spores, see Koch, 'Die Ätiologie der Tuberkulose' (1882), op. cit., note 16 above, p. 431; Koch, 'Die Ätiologie der Tuberkulose' (1884), op. cit., note 19 above, p. 491 , and ill. 47.

${ }^{56}$ Ibid. (1884), p. 509, where Koch discusses the infectious properties of tubercles in which no bacteria can be shown. On p. 502 he describes spores in tissues, on p. 526 in pure cultures. 


\section{Christoph Gradmann}

bacteria. The peculiarities of Koch's spores could pose a major threat, making the description of the tubercle bacillus' life cycle potentially incomplete. ${ }^{57}$

Finding the bacterium did indeed pose the main problem. By contrast, the difficulties in cultivation and inoculation could be tackled by modifying existing methods. Koch's point of departure was the reproduction of previous experimental work, most notably by Villemin and by Koch's Breslau colleagues Cohnheim and Weigert, which intended to demonstrate the unity of tuberculosis. Working on the level of microscopical anatomy, Koch showed the identity of different sorts of diseases such as pulmonary tuberculosis, lupus, and miliary tuberculosis, the identity of natural tuberculosis and tuberculosis caused by inoculation, and finally the identity of the disease in humans and susceptible animals. ${ }^{58}$

In the course of these extended series of experiments, guinea pigs, which had already been in widespread use in experimental work on tuberculosis, ${ }^{59}$ acquired a central position in Koch's work on tuberculous processes. Koch thought that they were almost ideal laboratory animals for his case, as they never caught tuberculosis under normal conditions. ${ }^{60}$ At the same time, they proved highly susceptible to inoculated tuberculosis and produced the pathological symptoms in regular and rapid fashion. ${ }^{61}$

Finally, pure cultures had to be attained and, later, inoculated, but the production of these encountered two peculiar difficulties. First, the bacteria grew only at temperatures above $30^{\circ} \mathrm{C}$, but the gelatine-based fixed culture media that Koch and his collaborators had employed previously liquefied at such temperatures. Second, since the cultures showed only a very slow growth, there was an additional high danger of contamination, i.e. that they were overgrown by other "fast" microorganisms. The solution to the first problem was found in new culture medium produced by coagulating blood serum, in the second it was-besides meticulous hygiene-again the guinea pigs that paved the way to success. Preparations from humans, i.e. corpses, proved to be much too dirty, instead an intermediate guinea pig-passage secured a much better point of departure for attaining pure cultures, since the rapid pathological process in those animals produced a more practicable tuberculous matter. ${ }^{62}$

\footnotetext{
${ }^{57}$ In fact, things went the other way: for subsequent authors the typically altered bacteria became entirely visible and lost their quality of being spores; the peculiar shape of the former "spores" was now taken to display the internal structure of the bacterium. Georg Cornet and Hermann Kossel, 'Tuberkulose', in Kolle and Wasserman, op. cit., note 53 above, 2nd ed., 1913 , vol. 5 , pp. $391-480$, on pp. $401-4$.

${ }^{88} \mathrm{Re}$-transmitting the disease from animals to humans, of course, was obliged to prove the identity of tuberculosis in humans and animals. Instead, Koch inoculated different sorts of anthropoid tuberculosis to 211 guinea pigs, rabbits and cats in various ways (subcutaneous, by inhalation, in the veins, etc.) in 28 series of experiments.

${ }^{59}$ For a survey of experimental work, see Predöhl, op. cit., note 21 above, pp. 181-244.
}

\footnotetext{
${ }^{60}$ Koch, 'Die Ätiologie der Tuberkulose' (1884), op. cit., note 19 above, p. 512. However, once the animals were kept in the laboratory, spontaneous cases of infection occurred if tuberculous and non-tuberculous ones were in mixed groups. The suspected mode of transmission was inhalation. Koch described these cases and observed their relatedness to human phthisis on the level of pathological anatomy.

${ }^{61}$ On Koch's use of laboratory animals, see Gerda Opitz, 'Tierversuche und Versuchstiere in der Geschichte der Biologie und Medizin', Diss. rer. nat., Friedrich-Schiller-Universität Jena, 1968, pp. $200-4$.

${ }^{62}$ Koch, 'Die Ätiologie der Tuberkulose' (1884), op. cit., note 19 above, p. 520.
} 


\section{Robert Koch and the Pressures of Scientific Research}

Tuberculous matter that was placed onto the nutritious medium was expected to show signs of growth not earlier than 10 to 15 days after preparation. It could then be cultivated further into pure cultures. Earlier growth was, of course, a sign of contamination. ${ }^{63}$ The "peculiar highly elegant" form of the cultures in the microscopic picture and their macroscopic appearance as "tiny little dots and dry looking small scales", which had to remain on the surface of the culture medium without dilution or penetration, were equally significant for the bacillus. ${ }^{64}$

The investigation was finally crowned by infection experiments with the pure cultures. A large number of different animals, most of them guinea pigs or rabbits, were inoculated in various ways, others were fed pure cultures or had to inhale them. In those animals susceptible to tuberculosis, Koch succeeded in producing the disease. ${ }^{65}$ The crucial point was that Koch not only succeeded in producing symptoms of tuberculosis, i.e. he could detect bacteria upon dissection, but that the disease brought forth by application of the pure cultures was-at the level of microscopical anatomy-identical with the one that had been produced previously by using tuberculous matter. This meant that with his pure cultures Koch had reproduced the inoculation-tuberculosis of Villemin and Cohnheim, and had supplied the missing link, the pathogen. ${ }^{66}$ In 1882 Koch concluded in the famous sentence: "All these facts justify the claim that the bacilli which occur in the tuberculous matter are not companions of the tuberculous process, but its cause, and that we can see the bacilli as the real [das eigentliche] tubercle virus." 67

In the 1882 presentation of his work, Koch had laid particular emphasis on the level of bacterial etiology, which was received without much discussion. Koch's meticulous way of proceeding seemed to exclude any doubt and even Rudolf Virchow, who would always remain sceptical of bacteriology, found no way of denying the bacterium's existence and importance. ${ }^{68}$ That Koch had to face few contradictions was, however, also due to the circumstance that his bacterial etiology of the disease was, despite its novelty, linked to previously developed conceptions of tuberculosis. Koch's own assessment that "phthisis [was held] amongst physicians to be a noninfectious disease, originating in constitutional anomalies"69 and that now "it was possible to draw the boundary of the disease that is seen as tuberculosis, which

${ }^{63}$ Ibid., p. 522.

${ }^{64}$ Koch, 'Die Ätiologie der Tuberkulose' (1882), op. cit., note 16 above, p. 435 . In 1884 Koch described the cultures of the bacillus as "fine multiple curved lines. The smallest have the shape of an S. Longer colonies show manifold snake-like coils which resemble entwined serifs." Koch, 'Die Ätiologie der Tuberkulose' (1884), op. cit., note 19 above, p. 525 .

${ }^{65}$ Koch did some control-experiments with non-infectious matter or on non-susceptible animals. In one of these experiments he inoculated no less than 13 different species including starlings, a goldfish, and a tortoise. (Ibid., p. 539.)

\footnotetext{
${ }^{66}$ Koch, 'Die Ätiologie der Tuberkulose' (1882), op. cit., note 16 above, p. 441.

${ }^{67}$ Ibid., p. 442.

${ }^{68}$ Rudolf Virchow, 'Der Kampf der Zellen und Bakterien', Arch. pathol. Anat. Physio., 1885, 101: 1-13. Virchow objected to the overestimation of the knowledge of the pathogen, which had in his eyes come to occupy "not only the thinking, but the dreams of many older and almost all young physicians"(p. 8). Cf. Hans-Uwe Lammel, 'Virchow contra Koch? Neue Untersuchungen zu einer alten Streitfrage', Charité Annalen, 1982, 2: 113-20.

${ }^{69}$ Koch, 'Die Ätiologie der Tuberkulose' (1884), op. cit., note 19 above, p. 467.
} 


\section{Christoph Gradmann}

previously could not have been done with certainty"70 was in a sense exaggerated. In fact, he had added a bacterial etiology to a conception of the disease that had been developed from Bayle via Laennec, Villemin down to Cohnheim. The bacterial etiology overlapped with older observations and could be seen as a confirmation of the older conception by employing new methods of proof. Koch's boundaries of the disease, based on a bacterial diagnosis, delimited precisely those pathological symptoms which had been claimed previously on the basis of the pathologicalanatomical structure of the tubercles; the identity of tuberculosis in humans and animals had been investigated by Villemin. ${ }^{11}$ This is even correct for the questions that remained open: scrofula, whose identification with tuberculosis had remained disputable for Villemin, could not be proved to be tuberculous by Koch either. ${ }^{72}$ To be clear: Koch's view contradicted the conceptions held by many pathologists who claimed the independence of phthisis and denied the connection of caseous pneumonia to tuberculosis. What Koch achieved was the establishment of a certain unified conception of tuberculosis as an infectious disease. ${ }^{73}$ Essential to this was an entire disregard of clinical evidence, which supplied only "the most uncertain results", 74 and gradual replacement of pathological anatomy as a means of definition of tuberculous tissues by a new criterion, the presence of bacteria: "the genuine tubercles are infectious and contain tubercle bacilli, the non-genuine do not". ${ }^{75}$ Once he had found them, the bacteria acquired a status of easy and indisputable concreteness. ${ }^{76}$ Koch promoted his bacteriological procedure as a simple-to-use tool for diagnosis since "anybody who has seen the manipulation once can easily do the staining of the bacteria himself". ${ }^{77}$

Koch's 1884 assessment of his work was not only a detailed one, it also contained a certain shift in rhetoric, which is significant. In 1882 Koch had carefully avoided

\footnotetext{
${ }^{70}$ Koch, 'Die Ätiologie der Tuberkulose' (1882), op. cit., note 16 above, p. 442.

${ }^{71}$ King, op. cit., note 21 above, p. 59. For a survey of numerous experimental studies following Villemin, see Predöhl, op. cit., note 21 above, pp. 163-349.

${ }^{72}$ Koch, 'Die Ätiologie der Tuberkulose' (1882), op. cit., note 16 above, p. 442.

${ }^{73} \mathrm{Cf}$. Faber, op. cit., note 23 above, pp. 99-101, who emphasized the connection of Koch's conception of tuberculosis to Villemin and Laennec. Cf. Johannes Orth, Ätiologisches und Anatomisches über Lungenschwindsucht, Berlin, Hirschwald, 1887 , p. 4 , who reminded his contemporaries of the instance "that Koch's discovery was in a certain sense only the coronation of an aetiologic building, which had by and large already been completed".

${ }_{74}$ Koch, 'Die Ätiologie der Tuberkulose' (1884), op. cit., note 19 above, p. 467.
}

\footnotetext{
${ }^{75}$ Ibid., p. 531. The centrality of guinea pigs in Koch's experiment reflects this shift. Rabbits, which had offered previous researchers a unique possibility to observe the growth of tubercles in the cornea of their eyes, were gradually replaced by guinea pigs, which offered a high and stable susceptibility.

${ }^{76}$ In 1883 Koch's answer to some of his critics could be rather rough and dismissive. It sufficed to do away with their arguments by pointing out technical errors, etc., even by making fun of them: "Sternberg could not find the bacteria and thereupon felt obliged to deny their existence. We hope that he has convinced himself of his error in the meantime." Koch, 'Kritische Besprechung', op. cit., note 18 above, p. 457.

${ }^{77}$ Koch to Justi, 27.9.1882, SBPK. The letter is printed in Heymann, Robert Koch Biographie. II., op. cit., note 11 above, pp. 35-6. Cf. Koch, 'Die Âtiologie der Tuberkulose' (1882), op. cit., note 16 above, p. 442 .
} 


\section{Robert Koch and the Pressures of Scientific Research}

placing his bacillus in sharp contradiction to other, non-bacterial factors in the etiology of tuberculosis. Disposition, heredity, and social conditions were explicitly named as being important. ${ }^{78}$ In 1884 the issue was treated in a much more selfconfident manner: disposition and heredity were now seen as residual categories, denoting phenomena which could not (yet) be explained by a bacterial etiology and pathogenesis of the disease. There remained "some facts which can be interpreted hardly or not at all, which force us to carry on employing the assumption of disposition for the time being". ${ }^{79}$

This meant that, in 1884, the issue of bacterial etiology was treated in a more general fashion. Koch presented the bacterial etiology of tuberculosis as summing up the techniques and methods developed by his school. His pointing to "well proven" methods and the extensive discussion of his famous "postulates" given in 1884 served as a rhetoric designed to raise the significance of his work. Consequently, Koch did not present his work as a result of eight months of investigation-he did not even mention this ${ }^{80}$ - but instead pointed to his anthrax studies as the point of departure. $^{81}$

In the twentieth century, bacteriology came to be regarded as a "watershed between traditional and modern medicine that is easy to see, but difficult to capture" ${ }^{82}$. This notion of a watershed echoes Koch's own ideas about the significance of his research. He presented his work on tuberculosis as a summary of the knowledge about the etiology of a single infectious disease into a bacterial theory of infectious diseases at large. He expected,

... that the elucidation which has been achieved about the etiology of tuberculosis will produce new evidence for evaluating the remaining infectious diseases and that the methods of investigation, which have been proven in the research on tuberculosis, will be useful while working on other infectious diseases. ${ }^{83}$

\section{Bacteria and Disease}

Koch's early work on tuberculosis has basically been assessed in two different ways by medical historians so far, neither of which, however, emphasizes a connection with his subsequent work on tuberculin. The social history of medicine has placed

\footnotetext{
${ }^{78}$ Koch is said to have mentioned to Löffler in 1882 that he did not expect a quick acceptance of his results. Even in 1884, Koch regularly supplied standard information on hereditary factors of the deceased patients who were the sources of his tuberculous matter. (Koch, 'Die Ätiologie der Tuberkulose' (1884), op. cit., note 19 above, pp. 504-5.)

${ }^{79}$ Ibid., p. 560.

${ }^{80}$ This information was supplied by Löffler, op. cit., note 1 above.

81 "Tuberculosis, in relation to understanding its etiology, is connected to anthrax. The tubercle
}

bacilli are in exactly the same relation to tuberculosis as the anthrax bacilli are to anthrax." Koch, 'Die Ätiologie der Tuberkulose' (1884), op. cit., note 19 above, p. 550.

${ }^{82}$ Nancy $J$ Tomes and John Harley Warner, 'Introduction to the special issue on rethinking the reception of the germ theory of disease: comparative perspectives', J. Hist. Med. Allied Sci., 1997, 52: 7-16, on p. 7.

${ }^{83}$ Koch, 'Die Ätiologie der Tuberkulose' (1882), op. cit., note 16 above, p. 444. 


\section{Christoph Gradmann}

it at the outset of the bacteriological era in hygiene and public health that led to the "medicalization" of entire societies in the late nineteenth century. The bacteriologists' conception of an "apolitical reason" ${ }^{84}$ of the pathogens stripped epidemics of any political meaning, turned them into exclusive objects of scientific investigation, lending legitimacy to extended socialization based on medical expertise. ${ }^{85}$ This interpretation can easily be linked to Koch's own understanding of his work, the application in the sphere of public hygiene being one of his principal demands ${ }^{86}$ In this perspective, the tuberculosis research of 1882-84 is linked with Koch's work on cholera from 1883 onwards, as with Koch's successful microbe-hunting of the early eighties which inaugurated the beginning of the reign of bacteriology in hygiene.

The second interpretation is evidently inspired by medical theory and is related to Koch's so-called "postulates": in this case the emphasis is on a particular conception of infectious disease related to necessary causes which rose with the dominance of Koch's bacteriology and which succeeded against an older pathological-anatomical conception of these diseases. ${ }^{87}$ This included a shift in the conception of diseases; formerly seen as internal organic processes, they now became externally caused phenomena. Etiology, which had been a concept applied to any sort of diseasecausation from climate to heredity or even pathogenic germs, became, in a decidedly bacterial version of pathogens as necessary and specific causes of diseases, an essential concept for late nineteenth-century medicine. Koch's tubercle bacillus is thus seen

\footnotetext{
${ }^{84}$ Most notably, Bruno Latour has told this story with regard to the effect of Pasteurian microbiology on French society. Bruno Latour and Steve Woolgar, Science in action: how to follow scientists and engineers through society, Cambridge, MA, Harvard University Press, 1987, pp. 115-16: "When Pasteur and the hygienists introduced the notion of a microbe as the essential cause of an infectious disease, they did not take the society to be made up of rich and poor, but rather of a different list of groups: sick contagious people, healthy but dangerous carriers of microbes, immunised people, vaccinated people, and so on." Cf. Bruno Latour, The Pasteurization of France, trans. Alan Sheridan and John Law, Cambridge, MA, and London, Harvard University Press, 1988 [1984]. The expression of an "apolitical reason" (unpolitische Vernunft ) was coined by Gorsboth and Wagner, op. cit., note 10 above, p. 142 .

${ }^{85}$ Classic studies are the books by Ute Frevert (Krankheit als politisches Problem 1770-1880. Soziale Unterschichten in Preußen zwischen medizinischer Polizei und Sozialversicherung, Göttingen, Vandenhoeck \& Ruprecht, 1984), Claudia Huerkamp (Der Aufstieg der Ärzte im 19. Jahrhundert. Vom gelehrten Stand zum professionellen Experten, Göttingen, Vandenhoeck \& Ruprecht, 1985), and Gerd Göckenjahn
}

\author{
(Kurieren und Staat machen. Gesundheit und \\ Medizin in der bürgerlichen Welt, Frankfurt am \\ Main, Suhrkamp, 1985). Alfons Labisch (Homo \\ Hygienicus. Gesundheit und Medizin in der \\ Neuzeit, Frankfurt, Campus, 1992) employs a \\ comparable conception. Cf. the relevant chapters \\ in Richard J Evans, Death in Hamburg: society \\ and politics in the cholera years 1830-1910, \\ Oxford, Clarendon Press, 1987; Paul Weindling, \\ Health, race and German politics between national \\ unification and Nazism 1870-1945, Cambridge \\ University Press, 1989. A critical overview of the \\ research based on the medicalization-concept can \\ be found in: Francisca Loetz, Vom Kranken zum \\ Patienten. "Medikalisierung" und medizinische \\ Vergesellschaftung am Beispiel Badens 1750-1850, \\ Stuttgart, Franz Steiner, 1993, pp. 19-41. \\ ${ }^{86} \mathrm{Koch}$, 'Die Ätiologie der Tuberkulose' \\ (1882), op. cit., note 16 above, pp. 444-5. \\ ${ }^{87}$ The principal contribution is Carter, op. cit., \\ note 24 above. Cf. Alfred S Evans, Causation and \\ disease: a chronological journey, New York and \\ London, Plenum Medical Book Co., 1993; Alfred \\ Grafe, 'Die sogenannten Kochschen Postulate', \\ Gesnerus, 1988, 42: 411-18; Victoria A Harden, \\ 'Koch's postulates and the etiology of AIDS: an \\ historical perspective', Hist. Philos. Life Sci., \\ 1992, 14: 249-69.
}




\section{Robert Koch and the Pressures of Scientific Research}

as a kind of keystone, crowning a building that began with his anthrax studies. ${ }^{88}$ His work from 1876 to 1884 thus resulted in the first complete bacteriological theory of the causation of infectious diseases. ${ }^{89}$

This is a valuable interpretation but questionable, because the scope of Koch's studies is reduced by an almost exclusive focus upon their etiological content. The extended discussion of questions concerning the microscopic pathological anatomy of diseased tissues, which Koch gave in his 1884 paper, may then appear to be of lesser importance. This, however, is a misconception. For example, Koch's proof of the identity of tuberculous processes in various species cannot be reduced to a description of their necessary causes. In Koch's 1884 version of the postulates bacterial etiology was explicitly connected to the claim that the distribution and proliferation of the bacteria offers an explanation of the pathological transformation:

Furthermore it is necessary to consider their [the bacteria's] relation to their surroundings, the conduct of nearby tissues in the organisms, to investigate their appearance in various stages of the disease and similar instances, which allow one to conclude, with more or less certainty, that there is a causal relation between those structures and the disease. ${ }^{90}$

Regardless of the infected organism, the bacilli are thought always to produce-on the microscopic level-similar symptoms, most notably, of course, the tubercles. This has to be seen in close connection with Koch's notion of bacterial specificity, which extended the role of microbes beyond etiology into the definition of diseases as such. The reproducibility of a certain disease by the inoculation of cultures of a given micro-organism established a relationship of mutual definition. The stability of bacterial species was attested by the constancy of their pathogenic effects, which in turn opened the possibility of proving the presence of a disease by the identification of pathogens. ${ }^{91}$

From the above vantage point, bacteria are viewed as more than necessary causes of a disease and it was indeed a prerequisite of Koch's investigations that their "behaviour", that is their proliferation and distribution in relation to the pathological symptoms, explained the pathological process. For example, when the "tuberculous process is in early origination and proceeding quickly, bacteria are to be found in large numbers"; when "The peak of the eruption of the tubercles has passed the bacilli become rarer and rarer ... In very slowly developing tuberculous processes, the interior of the giant-cells is usually the only place where bacilli are to be found."92

Yet Koch did not discuss the relation of bacteria to the surrounding tissues in the

\footnotetext{
${ }^{88} \mathrm{~K}$ Codell Carter, who is the dominant author for this interpretation, stresses that Koch's postulates are best and fully developed in the 1884 tuberculosis paper: Carter, op. cit., note 24 above.

${ }^{89}$ Andrew Mendelsohn's argument points in the same direction. He shows that basic decisions such as the one against the importance of virulence and in favour of an emphasis on bacterial specificity were made in the late 1870 s and early 1880s: 'Cultures of bacteriology: formation and transformation of a science in
}

France and Germany, 1870-1914', PhD Diss., Princeton University, 1996, ch. 3 in particular.

${ }^{90}$ Koch, 'Die Ätiologie der Tuberkulose' (1884), op. cit., note 19 above, p. 469. Cf. Carter, op. cit., note 24 above, p. 361 .

${ }^{91}$ Pauline M H Mazumdar, Species and specificity: an interpretation of the history of immunology, Cambridge University Press, 1995, pp. 66-7.

${ }^{92}$ Koch, 'Die Ätiologie der Tuberkulose' (1882), op. cit., note 16 above, p. 430. 


\section{Christoph Gradmann}

same fashion as that employed in his etiological argument. In contrast with the causal chains used to discuss bacteria as necessary causes, we find, especially in the 1884 paper, descriptions of regular relations between the behaviour of the pathogens and the development of the disease. These observations are only partially based on experimental knowledge, and they rely mainly on the relatedness of the bacteria's conduct with the microscopic pathological symptoms. Experiments on bacteria are accompanied by studies into the morbid anatomy of the disease on the microscopic level. These observations contain -in a much less straightforward and even somewhat metaphorical fashion-Koch's ideas on the pathogenesis of tuberculosis. ${ }^{93}$ Quantity, distribution and constellation of the bacteria form an analogy to the pathological process. For the purpose of this text it may suffice to note the essentials of that conception.

The basic assumption is that a healthy organism is entirely free from pathogens and that the "appearance of tubercle bacilli indicates the beginning of the tuberculous process". ${ }^{94}$ The number of bacteria is not without relevance, but, in principle, a single one will do. A certain form of miliary tuberculosis is explained as such "that a single infectious germ, a single bacillus is dispersed at the place in question". ${ }^{95}$ It is notable that invasion, infection, and eruption of the disease are almost identical in this conception. ${ }^{96}$ Differences in the pathological process on the microscopic level are now due to the peculiarities of the infected tissues, for example, caverns are created in the lungs.

What Koch stated was, of course, the simple model of infectious diseases as bacterial invasion that can be found in Edwin Klebs' work or in popular conceptions a little later. ${ }^{97}$ That pathogenic germs could be present in a healthy organism was at the time almost unthinkable. ${ }^{98}$ Fighting the disease was, in such a conception, more or less restricted to preventing penetration of the host organism's boundaries. Koch himself discussed the problems of penetration via the respiratory and digestive organs, and through wounds, as well as questions of transmission via dust, sputum, or food in considerable detail. ${ }^{99}$ Related issues were subjected to intensive research by Koch's school later on and sick patients were-starting in Koch's own workincreasingly recognized as a danger to their fellow humans. ${ }^{100}$

\footnotetext{
${ }^{93}$ Carter (op. cit., note 24 above, p. 367) observes that these relations can also be assessed as criteria of weak sufficiency for etiology.

${ }^{94}$ Koch, 'Die Ätiologie der Tuberkulose' (1884), op. cit., note 19 above, p. 516.

${ }^{95}$ Ibid., p. 558.

${ }^{96}$ A description of how phthisis starts provides an example: "In the first place only single or few bacilli reach the lung, which due to their slow growth are quickly enclosed by a cellular infiltration. [They] do not, however, perish in the cellular infiltration, instead they produce in a fashion similar to a miliary tubercle the centre for caseation and necrosis." Ibid., p. 498.

${ }^{97}$ On Klebs, see K Codell Carter, 'Edwin Klebs' criteria for disease causality', Medizinhist. $J ., 1987,22: 80-9$. On Koch's understanding of
}

disease as bacterial invasion, see Mendelsohn, op. cit., note 89 above, pp. 255-63. On popular conceptions, see Christoph Gradmann, 'Invisible enemies: bacteriology and the language of politics in imperial Germany', Science in Context, 2000, 13: 9-30.

${ }^{98}$ Koch recognized the problem of healthy carriers from 1892-93 onwards: Mendelsohn, op. cit., note 89 above, ch. 7 .

${ }^{99}$ Koch, 'Die Ätiologie der Tuberkulose' (1884), op. cit., note 19 above, pp. 551-7.

${ }^{100}$ As an introduction, see Myers, op. cit., note 21 above. Georg Cornet argued in favour of infection via dust, Carl Flügge put forward the case of sputum and finally Behring favoured food (milk). Koch, 'Die Ätiologie der Tuberkulose' (1884), op. cit., note 19 above, p. 554, "a phthisic 
The organism subjected to such an invasion was essentially seen as passive. It was used by the bacteria, which alone played the active part, as a sort of culture medium. In a notable analogy to his pure cultures, Koch analysed the so-called caseation inside the tubercles as resulting from exhaustion of a culture medium. Initially, the bacteria are easily nourished: "The younger and smaller the granules are, the more bacilli are found with greatest density in the centre." ${ }^{101}$ Upon the dissolution of the cells inside the tubercles, the bacteria, which can no longer nourish themselves, decline or undergo a transformation into spores. Their distribution, number, and transformation mirrored the morbid process, its calming from fresh tubercles to the caseous mass inside the tubercles:

... what remains is an even mass, which is no longer accessible to nuclear staining and in which all previously present cells have died. This mass forms what has previously been considered the essential of the tubercle, the carrier of the infectious substance, in fact, its caseous centre. However, the caseous substance usually contains very few bacteria... . very soon the bacteria undergo further transformations, they decline or enter the stage of generating spores, in which they lose their ability to be stained. ${ }^{102}$

Thus, fresh tubercles, which contain many bacteria, are far more important for the propagation of the disease than the caseous ones which contain almost no bacteria. The propagation of the bacteria, which have no independent ability for motion, is in principle a passive process. It results either from the growth of their colonies or from being carried away by other cells. In contrast to this statement, the language that Koch uses to describe the diffusion of the pathogens in the organism ascribes them an active role. "It looks as if with the increasing number of bacilli their attitude towards the cells becomes a more active one." The bacteria "push themselves" onto the edge of a cell "press themselves in between the nuclei". ${ }^{103}$ They almost build military formations, nuclei and bacteria hold each other "in check". Depending on the intensity of the tuberculous process, the giant cells are finally "blasted" or remain as ruins, resembling "extinct craters" 104 of volcanoes.

After infection, the cells have no chance to escape necrosis, and the body has none of recovery. An organism infected with tuberculosis will decline. Koch's basic assumption is obvious in the interpretation he gives of one of his animal experiments. $\mathrm{He}$ had injected a dog with $0.5 \mathrm{~cm}^{3}$ pure culture in the peritoneal cavity. Much to his surprise, the animal recovered after the initial symptoms: "This is the only case of tuberculosis in animals that I have seen to develop into healing". ${ }^{105}$ In fact, Koch had killed most of his laboratory animals for the purpose of dissection and was unable to judge on the issue from his evidence. An non-substantiated conclusion like this can best be explained by the circumstance that for Koch the lethal outcome

[is] perfectly able to supply his close surroundings with great quantities of infectious matter in a form, which is best suitable for infection." One of the consequences of Koch's work was that phthisics in particular increasingly came to be treated in hospitals instead of their homes from the 1880 s onwards (Leonard G Wilson, 'The historical decline of tuberculosis in Europe and
America: its causes and significance', J. Hist. Med. Allied Sci., 1990, 45: 366-96, on p. 381).

${ }^{101}$ Koch, 'Die Ätiologie der Tuberkulose'

(1884), op. cit., note 19 above, p. 491.

${ }^{102}$ Ibid., p. 485.

${ }^{103}$ Ibid., p. 487.

${ }^{104}$ Ibid., p. 490.

${ }^{105}$ Ibid., p. 546. 


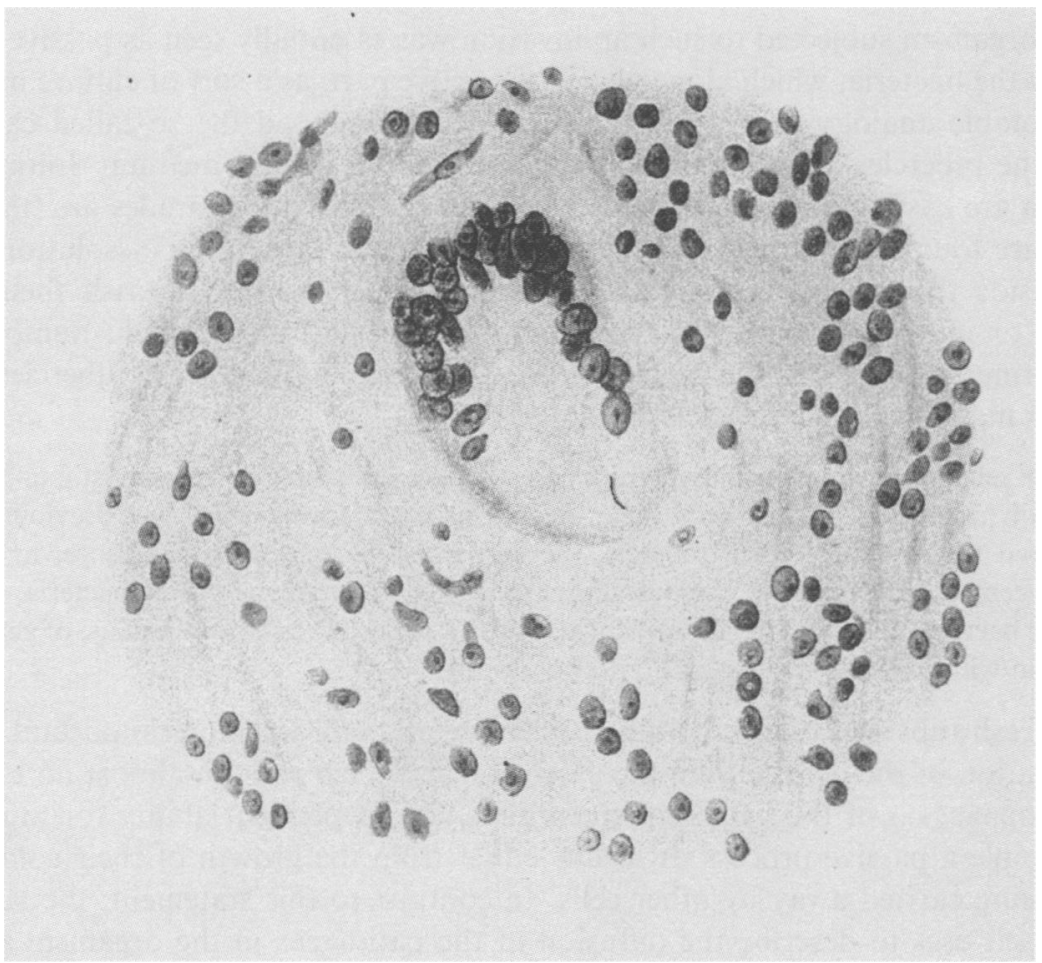

Figure 2: The drawing shows a bacillus opposing a group of nuclei inside a giant cell. From Koch's 'Die Ätiologie der Tuberkulose' (1884), in Gesammelte Werke von Robert Koch, ed. J Schwalbe, Leipzig, George Thieme, 1912, table 25, fig. 29. His description of the contents appears on p. 487.

of the tuberculous process was beyond doubt. Phenomena like spontaneous healing or delayed pathological processes are discussed nowhere in his texts-and indeed, amongst the guinea pigs upon which Koch's experimental knowledge was almost entirely based, these phenomena never occurred.

Koch seems to have regarded his description of disease as bacterial activity as sufficient. Even if he did not say so explicitly, the disregard with which factors such as disposition and heredity were treated in the 1884 paper provides evidence of this: as mentioned above, both were taken to denote phenomena which would sooner or later be explained by a bacterial conception of the disease.

Koch's work on the etiology of tuberculosis is thus connected to speculative pathology and contained a general concept of infectious diseases as bacterial activity. Disease was not, as Virchow had conceptualized it, life under modified conditions. ${ }^{106}$ Instead, Koch combined experimental knowledge about the bacteria's conduct with a decidedly ontological conception of diseases as autonomous beings-embodied in

${ }^{106}$ Cf. Heinz David, Rudolf Virchow und die Medizin des 20. Jahrhunderts, eds. W Selberg and
H Hamm, Munich, Quintessenz-Verlag, 1993, ch. 3. 


\section{Robert Koch and the Pressures of Scientific Research}

the pathogen. This identification of the cause and essence of disease resulted in the sweeping reductionist move: a description of the bacteria, their properties, distribution, and behaviour in infected tissues replaced systematic discussion of pathological processes. Disease is now one of the properties of the micro-organisms and the pathological content in Koch's work on tuberculosis is largely implicit. Ontological disease conceptions, which had been banned in German medicine for decades, were thus reintroduced by bacteriology. ${ }^{107} \mathrm{~A}$ dismissal of explicit and systematic discussions in combination with a rationalistic simplification can even be seen as a central feature of Koch's thinking on disease. ${ }^{108}$

Koch was well aware of the implications of his etiological thinking and stressed that it "makes a deep crack in the existing systems and forces a break with old and well-loved traditions". ${ }^{109}$ Edwin Klebs had, since 1878, made explicit claims for a bacterial etiology of all infectious diseases and had gained a reputation for bacteriological "extremism". Koch did not engage in verbal attacks à la Klebs, still, his implicit assumptions show a no less radical bacteriological reductionism - and maybe a borrowing from Klebs that went far beyond Koch's postulates. ${ }^{110}$

\section{Tuberculin}

Once the question of tuberculosis had found an answer, the obvious next step was into prevention and therapy. Koch himself proclaimed that this was indeed not a big one: in 1882, he took the identification of the cause to be almost a promise of control, since "[i]n future the fight against this horrible plague of mankind will no longer deal with an undefined something, but with a concrete parasite, whose living conditions are uncovered at large". ${ }^{111}$ Measures against the disease could now be developed under "particularly favourable conditions" $" 112$ and they included both general preventive measures, such as the disinfection of sputum, and more specific ones that concentrated on vaccines and even therapies for the infected patient.

In Koch's detailed account of 1884, a number of reflections concerning remedies against tuberculosis can be found. Initially, Koch seems to have attempted the

\footnotetext{
${ }^{107}$ Faber, op. cit., note 23 above, p. 94.

${ }^{108}$ Paul Diepgen, 'Krankheitswesen und Krankheitsursache in der spekulativen Pathologie des 19. Jahrhunderts', Sudhoffs Arch., 1926, 18: 302-27; Dietrich von Engelhardt, 'Kausalität und Konditionalität in der modernen Medizin', in H Schipperges (ed.), Pathogenese. Grundzüge und Perspektiven einer theoretischen Pathologie, Berlin and New York, Springer, 1985, pp. 32-58. Georges Canguilhem held a rationalistic simplification and decline in systematic pathological discussion to be essential for the bacteriological understanding of disease as a whole: Georges Canguilhem, 'Bacteriology and the end of nineteenth-century "medical theory", in idem, Ideology and rationality in the history of the life sciences, Cambridge, MA, and London, MIT Press, 1988, pp. 51-77.
}

\footnotetext{
${ }^{109}$ Koch, 'Kritische Besprechung', op. cit., note 18 above, p. 455 .

${ }^{110}$ Carter, op. cit., note 97 above. Edwin

Klebs, 'Uber Cellularpathologie und

Infectionskrankheiten', Tageblatt der 51.

Versammlung Deutscher Naturforscher und Aerzte in Cassel 1878, 1878, pp. 127-34. Cf. Mazumdar, op. cit., note 91 above, pp. 86-7.

${ }^{111}$ Koch, 'Die Ätiologie der Tuberkulose' (1882), op. cit., note 16 above, p. 444 . Cf. Faber, op. cit., note 23 above, pp. $110-11$ on the expectations of specific remedies being raised by the discovery of bacteria.

${ }^{112}$ Koch, 'Die Ätiologie der Tuberkulose' (1882), op. cit., note 16 above, p. 445 .
} 


\section{Christoph Gradmann}

attenuation of the bacteria. Even if a tuberculosis vaccine, produced " $\grave{a}$ la Pasteur", would have greatly underlined the usefulness of the knowledge of the bacterium, this is somewhat surprising. Koch was highly sceptical of bacterial virulence, the concept on which Pasteur had based his experiments on attenuation. ${ }^{113}$ In fact, at almost the same time, he was trying to refute Pasteur's anthrax vaccine and engaged in a vigorous debate on the issue. ${ }^{114}$ Indeed, from his strategy of work it looks more as if he was trying to provide evidence for the impossibility of a tuberculosis vaccine. First he demonstrated that an infection-even if the patient survived-did not produce immunity to the disease. The evidence for this was supplied by the above mentioned dog experiment, which was continued with the aim of proving that even in the rare case of a successfully withstood infection, immunity was not produced in the case of tuberculosis. A renewed inoculation with a quadrupled dose of two cubic centimetres did produce the desired result, i.e. the dog's death. Secondly, Koch could point to failed attenuation trials at the Imperial Health Office. ${ }^{115}$ Finally, he reported that cultures which had grown for up to two years in succession in his laboratory "did not show the slightest alteration of their properties, in particular, of their virulence". 116

An attempt to exploit the knowledge gained about the living conditions of bacteria, which Koch had acquired in his laboratory, and to link it to his work on disinfection seemed to be more promising. ${ }^{117}$ Together with Georg Gaffky, Koch started a series of experiments on this. Substances which had proved to be effective in keeping the bacteria from growing in test tubes were expected to produce a similar effect in organisms. ${ }^{118}$ However, substances like arsenic, which had been applied in previous medicinal therapies against the disease, turned out to be as ineffective as they had before. ${ }^{119}$ Contrary to earlier announcements, Koch never published these results and in 1886 the Imperial Health Office reported the end of the unsuccessful trials. ${ }^{120}$

In the mid-1880s Koch's attempts to find a specific remedy against tuberculosis seem to have led him nowhere. That raises the question of how the work on the pathogen connected to the work on the cure. In fact, Koch did not publish anything on the issue of tuberculosis until he made his sensational announcement of a remedy against the disease at the Tenth International Medical Congress, in August 1890, in Berlin. $^{121}$ The initial publications from 1882 to 1884 , and the papers on tuberculin from 1890 onwards, are thus separated by years of silence.

There are indications that these years should not be considered a period of fruitful

${ }^{113}$ Mendelsohn, op. cit., note 89 above, ch. 3.

${ }^{114}$ Brock, op. cit., note 7 above, ch. 16; Heymann, Robert Koch Biographie II, op. cit., note 11 above, pp. 36-46. Cf. K Codell Carter, 'The Koch-Pasteur dispute on establishing the cause of anthrax', Bull. Hist. Med., 1988, 62: 42-57.

${ }^{115}$ Ernst Schill and Bernhard Fischer, 'Über die Desinfektion des Auswurfs der Phthisiker', Mittheilungen aus dem Kaiserlichen Gesundheitsamte, 1884, 2: 131-46.

${ }^{116}$ Koch, 'Die Ätiologie der Tuberkulose' (1884), op. cit., note 19 above, p. 552.

\footnotetext{
${ }^{117}$ Brock, op. cit., note 7 above, ch. 12.

${ }^{118}$ Koch, 'Die Ätiologie der Tuberkulose' (1884), op. cit., note 19 above, p. 540.

${ }^{119}$ Ibid., p. 543.

${ }^{120}$ Möllers, op. cit., note 2 above, p. 556.

${ }^{121}$ Robert Koch, 'Über bakteriologische Forschung', in Gesammelte Werke, op. cit., note 8 above, vol. 1, pp. 650-60. Detailed accounts of the tuberculin affair are to be found in Elkeles, "“Tuberkulinrausch"'; Gradmann; and Opitz and Horn, all cited in note 10 above.
} 


\section{Robert Koch and the Pressures of Scientific Research}

investigation of other issues - on the contrary, they bear all the signs of a private and professional crisis. After his work on cholera in 1884, Koch's steady flow of publications dried up and it even seems that he did no research at all for some time.

There were practical reasons for this: Koch had tried in 1885 to leave the Imperial Health Office and to acquire a state-funded bacteriological research institute of his own. ${ }^{122}$ The plan failed and Koch ended up with a newly-created chair of hygiene at the University of Berlin. This Hygiene Institut was created against stiff resistance from the university, notably the faculty of medicine. ${ }^{123}$ The institute allowed the introduction of training courses in bacteriology for civil and military physicians, civil servants etc., on a considerable scale and was therefore important for the spread of bacteriological knowledge. ${ }^{124}$ However, Koch found himself in a very unsatisfactory situation. His position in the faculty remained precarious; extended everyday duties such as teaching, conducting examinations, etc. annoyed him; his deteriorating health imposed interruptions on his work; ${ }^{125}$ and private problems arose which, in 1890, led to Koch's separation from his first wife. ${ }^{126}$

Apart from all this, Koch was facing conceptual obstacles. His successes had so far depended more or less on spectacular identifications of pathogens. The application of this work turned out to be more or less confined to non-specific preventive hygiene, e.g. disinfection. Specific therapies for infected patients based on bacteriological knowledge, which had seemed so close in the early eighties, were nowhere to be seen. ${ }^{127}$ In the meantime, Pasteur in Paris had developed his vaccines, which were-even if not therapeutic devices-specific ones. They tremendously increased the reputation of French microbiology, and their material and immaterial profits enabled Pasteur to build his own research institute, the Institut Pasteur, in Paris. ${ }^{128}$ Meanwhile, Koch had nothing comparable to offer. In fact, when he resumed his work, he did not simply pick up his objects of research where he left them circa 1885 . We have every indication that the years from 1885 to 1890 were not an interruption, but a break in his career. This has been interpreted as a tragic feature in the career of a researcher who never again produced anything like his early successes, ${ }^{129}$ but others have pointed

\footnotetext{
${ }^{122}$ See Bernhard Opitz, 'Robert Kochs Ansichten über die zukünftige Gestaltung des Kaiserlichen Gesundheitsamtes', Medizinhist. J., 1994, 29: 363-77.

${ }_{123}^{123}$ See Eschenhagen, op. cit., note 10 above.

${ }^{124} \mathrm{On}$ the importance of the bacteriological courses in the Hygiene Institut, see Eschenhagen, op. cit., note 10 above; Mendelsohn, op. cit., note 89 above, pp. 280-5; Patricia Peck Gossel, 'A need for standard methods: the case of American bacteriology', in A Clarke and J Fujimura (eds), The right tools for the job: at work in twentieth century life sciences, Princeton University Press, 1992, pp. 287-311.

${ }^{125}$ Möllers, op. cit., note 2 above, pp. 185-90.

${ }^{126}$ Ibid., p. 192; Paul Weindling, 'Scientific elites and laboratory organisation in fin de siècle Paris and Berlin. The Pasteur Institute and Robert Koch's Institute for Infectious Diseases
}

compared', in Cunningham and Williams (eds), op. cit., note 32 above, pp. 170-88, on p. 176.

${ }^{127}$ Cf. Christoph Gradmann, " "Auf Kollegen zum fröhlichen Krieg". Popularisierte

Bakteriologie im Wilhelminischen Zeitalter', Med. Ges. Gesch., 1995, 13: 35-54, p. 39.

${ }^{128}$ On Pasteur's vaccines, see Geison, op. cit., note 15 above, pt 3 . On the foundation of the Institut Pasteur, see Ilana Löwy, 'On hybridizations, networks and new disciplines: the Pasteur-Institute and the development of microbiology in France', Stud. Hist. Philos. Sci. 1994, 25: 655-88. For a comparison of the Institut Pasteur to Koch's Institut für Infektionskrankheiten, see Weindling, op. cit., note 126 above.

${ }^{129}$ Most explicitly in Foster, op. cit., note 14 above, who describes Koch's later work a the tragic attempt to renew his earlier successes. 


\section{Christoph Gradmann}

to the fact that Koch's interest in the 1890s shifted from etiology to epidemiology, and, as such, has a value of its own. ${ }^{130}$

For the purpose of this paper, the question is whether and how Koch's tuberculin is related to his earlier work. There is some indirect evidence for such a connection, namely the far-reaching pathogenetic ideas which Koch developed while investigating the etiology of tuberculosis and the related experiments on therapies. Koch, in the early 1880 s, considered the issue of tuberculosis as essentially closed and took the knowledge of the pathogen to be a promise of therapy. In addition, there is some evidence that, despite positive results, Koch continued-in secret-to search for a tuberculosis cure. ${ }^{131}$ On 1 December 1886 , Koch wrote to his friend and colleague Carl Flügge: "Since my return from vacation I have indeed resumed experimental work with all enthusiasm. However, the task that $\mathrm{I}$ am into is of a somewhat extended nature, and it may well take years before I reach a conclusion." 132 A letter which Koch wrote to the Farbwerke Lucius \& Brüning (later, Hoechst) in 1888, shows that he was engaged in studies on the anti-bacterial effects of dyes:

The aim of my investigations is to test the effect that a number of substances of the aromatic group produce on pathogens and I have initially employed dyes, [illegible, most likely "since"] they were easiest to obtain. In the near future, however, I will be concerned with other substances and will permit myself to make use of your kind offer and ask for one or the other preparation, which is not traded. ${ }^{133}$

Koch's sensational announcement in August $1890^{134}$ should therefore be regarded as a stroke of liberation. With the remedy that became available in October, Koch triggered a euphoria which matched the spectacular successes of the early eighties. ${ }^{135}$ At the same time, it seemed that Koch's remedy, which later on became known as tuberculin, surpassed Pasteur's vaccines in being the first specific therapy for an infectious disease based on bacteriological science. ${ }^{136}$ It seemed to promise its inventor extraordinary commercial prospects-Koch himself calculated that the expected revenues would amount to several million Reichsmark annually! ${ }^{137}$ It also offered a way out of the dead-end, which seems to have been how Koch experienced his position in the Hygiene Institut, and prospects of an institutional position that equalled Pasteur's. Indeed, within less than a year, Koch found himself the first

${ }^{130}$ Mendelsohn, op. cit., note 89 above.

${ }^{131}$ The notion of a purposeful search is most explicitly held by Eschenhagen, op. cit., note 10 above, p. 113. On Koch's secrecy, see Möllers, op. cit., note 2 above, pp. 192-3.

${ }^{132}$ Koch to Flügge, 1.12.1886, Robert Koch Correspondence, Henry Barton Jacobs Collection, Johns Hopkins Institute of the History of Medicine/Baltimore, Cf. Möllers, op. cit., note 2 above, p. 184.

${ }^{133}$ Koch to Farbwerke Höchst, 23.5.1888, SBPK. Cf., Koch, 'Über bakteriologische Forschung', op. cit., note 121 above, p. 659.

${ }^{134}$ On the pompous surroundings of Koch's lecture, see Gorsboth and Wagner, op. cit., note
10 above; Rolf Winau, 'Serumtherapie: Die Entdeckung eines bahnbrechenden

Therapieprinzips im Jahr 1890', Dtsch. med. Wochenschr., 1990, 115: 1883-6.

${ }^{135}$ It should be noted that the peak of the tuberculin-euphoria was accompanied by a spreading of bacteriological metaphors in common language: Gradmann, op. cit., note 127 above, pp. 45-50.

${ }^{136}$ On Pasteur's vaccines on the example of rabies, see Geison, op. cit., note 15 above, ch. 8 in part. On Koch's intentions, cf. Foster, op. cit., note 14 above, p. 59. 56-7. 


\section{Robert Koch and the Pressures of Scientific Research}

director of a newly founded institute for infectious diseases in Berlin. ${ }^{138}$ Finally, tuberculin was supposed to fulfil the therapeutic promises that Koch had nurtured in himself and others. In 1882 Koch had solved the riddle of tuberculosis, now it was high noon for the disease! Koch himself saw a decisive battle "in fighting the smallest, but most dangerous enemies of mankind". ${ }^{139}$

It is, however, not an easy task to reconstruct the therapeutic effect of tuberculin as Koch envisioned it. The explanation for this difficulty is to be found less in the rapid failure of the substance, than in Koch's reluctance to supply information on previous research, components, testing, and the supposed effect of his remedy. His way of revealing any of the secrets of tuberculin came close to deception. In his first publication, he gave a misleading account of his research strategy. On the road to tuberculin, Koch had, as he remarked, "tested for some time a large number of substances to see whether they can influence tubercle bacilli grown in pure cultures" ${ }^{140}$ This relates tuberculin to the trials of 1883 and places them in connection with disinfection. The aim of these experiments had been to find substances in a test tube that were capable of preventing the growth of bacteria in organisms. In August 1890 , Koch claimed to have discovered such a substance:

I can tell ... that much, that guinea pigs, which are highly susceptible to the disease, no longer react upon inoculation with tubercle virus when treated with that substance and that in guinea pigs which are sick [with tuberculosis] the pathological process can be brought to a complete standstill. ${ }^{141}$

This was an opaque way of explaining what he had found and it obscured the fact that tuberculin was an extract from cultures of tuberculosis bacteria and thus entirely different from any of the substances Koch had experimented with earlier. Placing tuberculin within the tradition of disinfection was misleading but useful: it employed the successful tradition of Koch's previous work in order to lend the remedy credibility and obscured what seems to have been a far-reaching modification in Koch's investigative strategy some time between 1884 and $1890 .{ }^{142}$

In the following months, Koch showed considerable hesitation about giving more information on tuberculin and did so only when put under pressure. When tuberculin became available in October, he reported in some detail the reactions to the substance he had observed in animals and humans, but said nothing about the components. ${ }^{143}$ Only when, around the turn of the year, the tuberculin euphoria gave way to much more critical assessments, and Koch came under pressure from the public and

\footnotetext{
${ }^{138}$ In more detail: ibid., pp. $57-9$ in particular. It should be noted, however, that, despite the fact that Koch managed to leave the university position, the institute for infectious diseases was not quite what he had aimed for.

${ }^{139}$ Koch, 'Uber bakteriologische Forschung', op. cit., note 121 above, p. 660.

${ }^{140}$ Ibid., p. 660.

${ }^{141}$ Ibid., p. 659.

${ }^{142}$ There is almost no evidence as to when the modification did occur. The above cited letter to the Farbwerke Lucius \& Brüning of May 1888,
}

however, gives some indication that in 1888 Koch had not entirely given up his initial project of attacking the bacteria inside the body.

${ }^{143}$ Robert Koch, 'Weitere Mitteilungen über ein Heilmittel gegen Tuberkulose', in Gesammelte Werke, op. cit, note 8 above, vol. 1, pp. 661-8. The justification that Koch gave for his secrecy was the supposedly difficult process of producing tuberculin. Be this as it may, the secrecy certainly served to protect his aim to exploit tuberculin commercially (Gradmann, op. cit., note 10 above, pp. 56-7). 
Christoph Gradmann



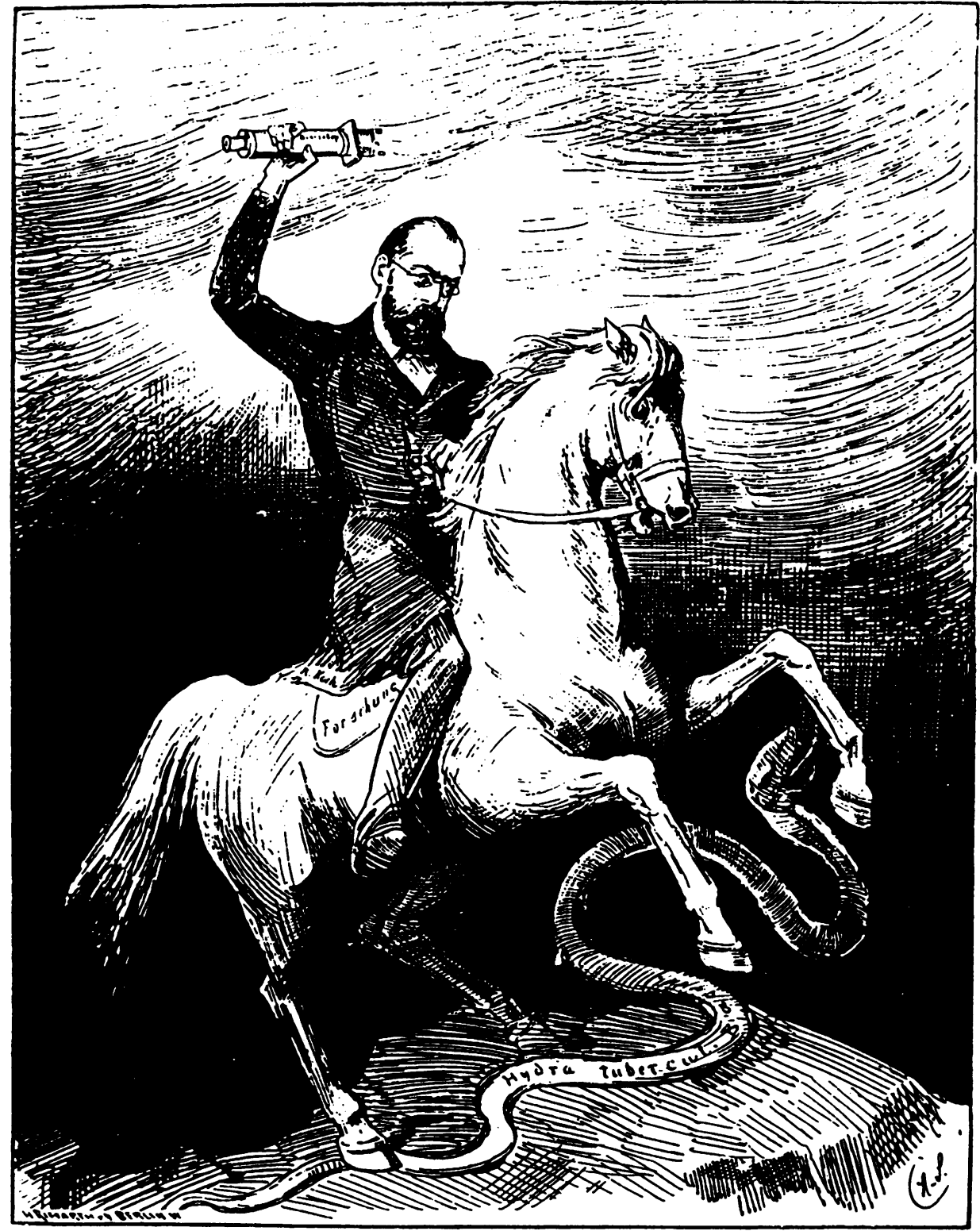

Der aene bitter st. Georg.

Figure 3: A new St George. The cartoon shows Koch as St George, sitting in the saddle of "Forschung" (research) and fighting a "Hydra Tubercul. Bacillus". A microscope serves as a sword. ('Der neue Ritter St. Georg', Ulk, 14 Nov. 1890, p.8.) 


\section{Robert Koch and the Pressures of Scientific Research}

Prussian government officials did he give a short and rather general description of the substance. ${ }^{144} \mathrm{Up}$ until that time "the doctors of the world had been experimenting with an entirely unknown substance, a 'secret remedy', in which they trusted solely on the basis of Robert Koch's name". ${ }^{145}$

Koch's revelation of the components of tuberculin was only one of a number of reasons for the quick decline in its popularity in early 1891. Rumours spread towards the end of the year that among other profiteers, Koch himself planned to earn a fortune from the remedy. ${ }^{146}$ When serious doubts were raised about tuberculin's therapeutic effect, he was unable to show the guinea pigs he had "cured" with it! Simultaneously, there were reports of deterioration among patients undergoing treatment and even of fatalities. Tuberculin was finished. ${ }^{147}$ The secrecy that had been part of the sensation in the first instance, now rebounded on its originator. Koch had developed tuberculin with the help of two rather minor bacteriologists, Eduard Pfuhl and Arnold Libbertz. Both were, however, notably trustworthy-Pfuhl being Koch's son-in-law and Libbertz a friend from Koch's youth. None of his more prominent colleagues or his other assistants at the Hygiene Institut knew about the composition of tuberculin. Testing in humans had initially been restricted to Koch himself and his 17 -year-old mistress! ${ }^{148}$ In early 1891 , it was shown that fresh tubercles could develop on the boundaries of tissues narcotized by tuberculin and Koch's conception, which had first of all relied on the understanding of this necrosis, was quickly refuted. ${ }^{149}$ Whether the necrosis had no effect at all on the propagation of the disease or whether it even speeded up the pathological process remained an open question, Koch's conception was wrong anyway. In late 1891, Paul Baumgarten, codiscoverer of the bacterium and a tuberculosis researcher, gave a devastating summary

\footnotetext{
${ }^{144}$ Robert Koch, 'Fortsetzung der

Mitteilungen über ein Heilmittel gegen

Tuberkulose', in Gesammelte Werke, op. cit, note 8 above, vol. 1, pp. 669-72.

${ }^{145}$ Elkeles “"Tuberkulinrausch"', op. cit., note 10 above, p. 1731. The names under which the substance became known prior to being called tuberculin are revealing, since they were either insignificant or point in wrong directions: "Koch's remedy" or "Koch's lymph" were in widespread use and the substance was frequently described as a therapeutic vaccine (Heilserum). Whatever tuberculin was, it was certainly neither a serum nor did it contain lymph. Cf. Gradmann, op. cit., note 127 above, pp. 45-6.

${ }^{146}$ This was in fact what he was up to: Gradmann, op. cit., note 10 above, pp. 56-7.

${ }^{147}$ Rudolf Virchow, 'Ueber die Wirkung des Koch'schen Mittels auf innere Organe Tuberkulöser', Berl. klinische Wochenschr., 1891, 28: 49-52. Virchow's article appears to indicate the turning point for the discussion of tuberculin in the medical public: anon., 'Redaktionelle Mitteilung', Berl. klinische Wochenschr., 1891, 28: 86. Cf. Die Wirksamkeit des Koch'schen Heilmittels gegen Tuberkulose. Amtliche Berichte der Klinken, Polikliniken und pathologisch-
}

anatomischen Institute der preussischen Universitäten', Klinisches Jahrbuch (supplementary volume), 1891. Cf., Elkeles, “"Tuberkulinrausch", op. cit., note 10 above, p. 1731. On the international reception of tuberculin, see Michel Chauvet, 'Une Centenaire qui n'a pas tenu toutes ses promesses', Rev. méd. Suisse Romande, 1990, 110: 1067-70; Bert Hansen, 'New images of a new medicine: visual evidence for the widespread popularity of therapeutic discoveries in America after 1885', Bull. Hist. Med., 1999, 73: 629-78; David Leibowitz, 'Scientific failure in an age of optimism: public reaction to Robert Koch's tuberculin cure', N. Y. State J. Med., 1993, 93: 41-8; Francis Barrymore Smith, The retreat of tuberculosis 1850-1950, London, Croom Helm, 1987, pp. 57-62.

${ }^{148}$ Hans Schadewaldt, 'Die Entdeckung des Tuberkulins', Dtsch. med. Wochenschr., 1975, 100: 1925-32. Later on some of Koch's assistants (Wassermann, Kitasato etc.) served as test persons. Koch, 'Weitere Mitteilungen über ein Heilmittel gegen Tuberkulose', op. cit., note 143 above, p. 679 .

${ }^{149}$ Virchow, op. cit., note 147 above. 


\section{Christoph Gradmann}

of the animal testing of tuberculin, stating "that large doses cause damage in the case of a developed inoculated tuberculosis, whereas small doses don't help."150

How did Koch come to think of tuberculin as a cure for tuberculosis? Upon what observations and considerations did he base his claim that he had a remedy against the disease? The answer to these questions is not to be found where one would expect it, i.e. in tuberculin. In the course of 1891, it was revealed that tuberculin was a riddle to everybody including the inventor. Koch had tried in vain to isolate a single substance that produced the effect he observed, and further attempts by himself and others were fruitless. ${ }^{151}$

What remained to justify Koch's claims was thus the observed reaction of the organism to tuberculin, which Koch seems to have understood as a healing process. One of the central features of his older ideas about the development of the disease had been the transformation from an early, intensive stage that included the presence of many bacteria into an almost entirely bacteria-free stage of caseation and necrosis that was accompanied by a halting of the pathological process, since the bacteria found no more nourishment in the destroyed tissues. Tuberculin was, in Koch's eyes, intended to produce exactly this effect.

By animal experiments, Koch had reached the conclusion that guinea pigs, previously infected with tuberculosis, reacted in a peculiar way to a renewed inoculation. Where an inoculated tuberculosis was to be expected what followed instead was necrosis of the already tuberculous tissues. This particular observation laid the basis for Koch's understanding of tuberculin. The effect of the remedy on the organism was described as follows: "That much is clear that it is not a destruction of the tubercle-bacilli, which are in the tissues, instead only the tissue, which encloses the tubercle-bacilli, is affected by the impact of the remedy." 152 The necrosis, which Koch in 1884 had interpreted as a stalling of the disease, was produced. Bacteria which lay in the tissues were deprived of their culture medium and the pathological process came to a standstill. This conception, which can best be characterized as a bacteriological variation of a scorched-earth strategy, was based on the intention to be ahead of the bacteria and thereby prevent their propagation in the organism: "In the tissues that have turned necrotic the bacillus encounters unfavourable conditions

\footnotetext{
${ }^{150}$ Paul Baumgarten, 'Neuere experimentellpathologische Arbeiten über Tuberculinwirkung', Berl. klinische Wochenschr., 1891, 28: 1206-8, 1218-19, 1233-4, on p. 1208.

${ }^{151}$ Koch, 'Weitere Mitteilungen über ein Heilmittel gegen Tuberkulose', op. cit., note 143 above; idem, 'Weitere Mitteilung über das Tuberkulin', in Gesammelte Werke, op. cit., note 8 above, vol. 1, pp. 673-82. It should, however, be noted that the origin of tuberculin in pure cultures soon became known. Ferdinand Hueppe showed that they contained proteins and rightly pointed to the origin in tuberculosis purecultures. He did so even before Koch himself revealed the origin of the substance. Ferdinand
}

\author{
Hueppe and Hermann Scholl, 'Ueber die Natur \\ der Koch'schen Lymphe', Berl. klinische \\ Wochenschr., 1891, 28: 88-9. Later in 1891, \\ Hueppe wrote a principal critique of Koch's \\ publications on tuberculin: 'Robert Koch's \\ Mittheilungen über Tuberkulin. Kritisch \\ beleuchtet', Berl. klinische Wochenschr.,1891, 28: \\ 1121-2. Edwin Klebs announced what he thought \\ was an improved tuberculin in late 1891: 'Die \\ Zusammensetzung des Tuberkulin', Dtsch. med. \\ Wochenschr., 1891, 17: 1233-4. \\ ${ }^{152}$ Koch, 'Weitere Mitteilungen über ein \\ Heilmittel gegen Tuberkulose', op. cit., note 143 \\ above, p. 664 .
}




\section{Robert Koch and the Pressures of Scientific Research}

for feeding, which prevent it from growing any further and eventually lead to its death." 153

As a matter of fact, humans proved to be "much more sensitive"154 to the remedy than the guinea pigs. Whereas among the latter only the tuberculous ones displayed symptoms, in humans a general reaction to tuberculin including fever, shivering, pain in the limbs, and nausea was almost constantly to be found. Koch and his mistress had indeed been the first to experience this. In patients with acute tuberculosis, this was accompanied by a local reaction in tuberculous tissues. If the dose was lowered to $0.3 \mathrm{~cm}^{3}$ only tuberculous patients displayed symptoms, whereas, according to Koch's report, healthy persons showed only slight reactions or none at all. The local reaction could best be observed in tuberculosis of the epidermis, lupus. After the injection "the parts that show lupus start to turn red and they do so before shivering starts". Upon further development the tissues turn "brown-red and necrotic", the tuberculous parts are "transformed into scales (Borken), which fall off after 2-3 weeks and what remains, in some cases already following the first injection of the remedy, is a smooth red scar." 155

Besides the supposed therapeutic effect, Koch regarded the peculiar reaction of patients suffering from acute tuberculosis to the remedy as a diagnostic tool. Whereas healthy individuals showed only general symptoms if any at all, tuberculous individuals displayed both a strong general and a local reaction in infected tissues. Koch demanded the application of tuberculin as a diagnostic tool and it should be noted that his form of tuberculin test was entirely different from what it became later. It was supposed to serve as a diagnostic tool for the identification of an acute disease, whereas Clemens von Pirquet's test from 1907 onwards was intended to detect a (primary) infection and not an illness-no matter if acute or long healed. ${ }^{156}$ However, among Koch's contemporaries the diagnostic test received a much more favourable reception than the "curative" effect of tuberculin. ${ }^{157}$

\section{Deceptions}

The issue of Koch's ideas about tuberculin includes a question I have not yet posed: namely, whether he thought he had a remedy at all. The notion of a "tuberculin fraud" has been put forward by contemporaries and historians and some features of his conduct are indeed hard to comprehend, if one entirely excludes the notion of Koch being a deceiver. ${ }^{158} \mathrm{He}$ supplied scarce and misleading information about

\footnotetext{
${ }^{153}$ Koch, 'Fortsetzung der Mitteilungen über ein Heilmittel gegen Tuberkulose', op. cit., note 144 above, p. 672.

${ }^{154}$ Koch, 'Weitere Mitteilungen über ein

Heilmittel gegen Tuberkulose', op. cit., note 143 above, p. 662 .

${ }^{155}$ Ibid., p. 663.

${ }^{156}$ Silverstein, op. cit., note 13 above, pp. 230-2.

${ }^{157}$ For Koch's description of the reaction, see Koch, 'Weitere Mitteilungen über ein Heilmittel
}

gegen Tuberkulose', op. cit., note 143 above, $p$. 663. The positive assessment of tuberculin as a tool for diagnosis is stated by most authors in the official reports (Die Wirksamkeit des Koch'schen Heilmittels ..., op. cit., note 147 above).

${ }^{158}$ The phrase "tuberculin fraud"

(Tuberkulinschwindel) was coined by Johannes Orth: Schadewaldt, op. cit., note 148 above. Cf. Gorsboth and Wagner, op. cit., note 10 above, who give some insight into the public opinion on tuberculin. 


\section{Christoph Gradmann}

his cure, for example, by linking it rhetorically to the well-established and successful disinfection. When criticized, he was unable to show the guinea pigs he had cured with tuberculin. Further, the manner in which Koch pursued his commercial plans ended up in mutually attempted blackmail by himself and Prussian government officials. ${ }^{159}$

There is, however, almost no indication that Koch was deliberately misleading about the supposed effect of tuberculin. He seems to have firmly believed that tuberculin was a curative medium. He kept on working on the issue, presenting an improved tuberculin in 1897 , and remained faithful to his remedy at least until $1901 .^{160}$ Instead of employing the notion of simple fraud, it is seems more appropriate to analyse Koch's concept of tuberculin as resulting from the prolongation of a successful research programme that finally led to self-deception. It was Koch's conviction that he had, in 1882 , solved the riddle of tuberculosis which obstructed him in 1890, and kept him from asking new questions about the disease. To pose such questions, however, would have been a prerequisite for a different interpretation of the tuberculin effect.

While working on tuberculosis in the early 1880 s, Koch had sometimes reached what would seem to be strange interpretations of the facts he had observed, or came to conclusions which could hardly be sustained by his observations at all. In the context of his early work on tuberculosis, such observations remained without consequences. However, they do explain the disaster of $1890 .{ }^{161}$ His spores supply a fine example of this sort of observation. Visible or invisible, stainable or not, they nevertheless were central to his argument. The sometimes invisible spores made it possible to claim the constant presence of bacteria in diseased tissues and the enduring infectious properties of sputum. At the same time, the observed resistance of the spores to staining contained a nicely plausible explanation for that invisibility. ${ }^{162}$

Koch's spores illustrate the tenacity with which contradictory or inconclusive evidence was incorporated into a conception which Koch himself had attempted to canonize in the early $1880 \mathrm{~s} .{ }^{163}$ Koch's understanding of infectious diseases as bacterial invasion provides another, fundamental, example. It seduced him into equating the presence of bacteria with disease. Koch did not care to look for tuberculosis bacteria

\footnotetext{
${ }^{159}$ Gradmann, op. cit., note 10 above, p. 62.

${ }^{160}$ Robert Koch, 'Über neue Tuberculinpräparate', in Gesammelte Werke, op. cit, note 8 above, vol. 1, pp. 683-93; 'Über die Behandlung der Lungentuberkulose mit Tuberkulin', ibid., p. 693. Cf. on the history of tuberculin-therapy: Josef M Schmidt, 'Geschichte der TuberkulinTherapie-Ihre Begründung durch Robert Koch, ihre Vorläufer und ihre,weitere Entwicklung', Pneumologie, 1991, 45: 776-84.

${ }^{161}$ Such inconsistencies are more illuminating for a historical analysis than errors in Koch's work with regard to today's knowledge about tuberculosis, even if they are fundamental: e.g., Koch's assumption that tubercle bacteria produce a substance which produces necrosis in the surrounding tissues seems nonsensical today. The
}

mycobacterium tuberculosis is said to neither contain nor expel toxic substances, indeed these bacteria do not secrete anything into the organism at all! William D Johnston, 'Tuberculosis', in K F Kiple (ed.), The Cambridge world history of human disease, Cambridge University Press, 1994, pp. 1059-68.

${ }^{162}$ For Cornet and Meyer, op. cit., note 53 above, p. 81, bacteriologists of the Koch school, the spores had turned to "Vakuolen" and could now been identified regularly. The existence of spores seemed very improbable to the authors.

${ }^{163}$ Ludwig Fleck has identified this "harmony of illusions" as a central feature of the process of scientific investigations. Ludwik Fleck, Genesis and development of a scientific fact, University of Chicago Press, 1988 [1935]. 


\section{Robert Koch and the Pressures of Scientific Research}

in healthy humans, he was satisfied with proving their existence in diseased tissues and even this was achieved only with the help of his "spores".

Bacterial etiology had between 1882 and 1884 sufficed to explain the pathogenesis of tuberculosis and Koch refused to put the issue on the agenda again in 1890. His understanding of the tuberculin reaction itself can thus be best explained by an enormous pressure to bring new observations into line with the developed framework. The striking instance that healthy guinea pigs did not show a general reaction to tuberculin, whereas healthy humans did, was explained by a much higher sensitivity of humans to the substance. Koch estimated this differing sensitivity in the fantastic proportion of $1: 1,500 !^{164}$ Apart from being speculative, this statement was, with regard to the high susceptibility of the animals to the disease, almost bizarre. Furthermore, Koch had observed that his guinea pigs never acquired tuberculosis spontaneously, which humans did. Thus another, more accurate explanation, was right under his nose. However, to explain the tuberculin reaction as delayed hypersensitivity, as Clemens von Pirquet and others did later, was beyond Koch's reach. ${ }^{165}$ It would have required a clear distinction between infection and illness. In the $1880 \mathrm{~s}$, Koch made no such distinction, it was enough to know that tuberculin had an impact on tuberculous processes "of whatever kind they might be". ${ }^{166}$

Pirquet and others later came to regard the reaction as one of the organism's immune system and not of the bacteria, as Koch had done. The symptoms which he himself showed upon testing tuberculin could have puzzled Koch. However, he did not even question whether he himself was tuberculous, and his concept of tuberculin as a diagnostic tool is of a similar type: Koch did not employ the general reaction to point to a bygone primary-infection, instead the intensity and the localized character of the symptoms served to distinguish healthy from sick humans. ${ }^{167}$ Consequently, Koch lowered the dose to a level at which the reaction occurred only in those who were-in his eyes-tuberculous.

Further illustrations of the consequences of focusing on the pathogen can be found. Koch considered the disease resulted entirely from the activities of the bacteria and paid little attention to the differing pathologies of the disease in humans and laboratory animals. In his view, it was consistent to explain the absence of the tuberculin effect in guinea pigs by proportionate sensitivities. In fact, his laboratory animals were unlikely ever to have lived long enough to be able to show a general reaction to tuberculin. After all, Koch had chosen them for the rapidity of the pathological process. In Koch's "guinea pig-pathology" of tuberculosis, phenomena

\footnotetext{
${ }^{164}$ Koch, 'Weitere Mitteilungen über ein Heilmittel gegen Tuberkulose', op. cit., note 143 above, p. 662 . Koch injected healthy guinea pigs almost by the bucket and even two $\mathrm{cm}^{3}$ of tuberculin did not produce a reaction in the animals.

${ }^{165}$ On this, see Silverstein, op. cit., note 13 above, p. 229.

${ }^{166}$ Koch, 'Weitere Mitteilungen über ein Heilmittel gegen Tuberkulose', op. cit., note 143 above, p. 663 .
}

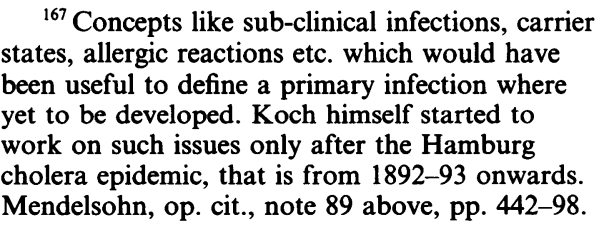
been useful to define a primary infection where yet to be developed. Koch himself started to Mendelsohn, op. cit., note 89 above, pp. 442-98. 


\section{Christoph Gradmann}

that could have pointed to a primary infection, and thus served for a different explanation of the tuberculin reaction in humans, did not occur. ${ }^{168}$

\section{Conclusion}

A summary and some conclusions can be drawn from this investigation of Koch's work on tuberculosis. A combined assessment of the initial research on tuberculosis in the early 1880s and Koch's conception of the tuberculin-cure offers important insights into his thinking on both infectious diseases in general and tuberculosis in particular.

Koch's early work on tuberculosis combined research into etiology with a concept of infectious diseases as bacterial invasion. However, whereas the etiological argument was developed in a systematic and explicit manner, most notably in the 1884 version of his "postulates", no comparable discussion of pathology can be found. Instead, it sufficed for Koch to give a description of the properties and conduct of bacteria which implied rather than explicitly stated a reductionist and ontological conception of infectious diseases.

Koch's research on infectious diseases was linked to a quest for measures of control, which seemed to lie in the near future in the early $1880 \mathrm{~s}$. The pressure exerted by such promises to himself, the scientific and wider public, matters of professional competition most notably with French microbiologists, and repeated refusals to put issues on the agenda which were regarded as closed since 1884, resulted in the tuberculin fiasco of 1890/91. Koch's explanation of the tuberculin reaction was strictly in line with his earlier work and the failure of tuberculin uncovers some peculiarities of Koch's understanding of tuberculosis: most notably its unreflected reliance on animal pathology and an understanding of disease as bacterial invasion that included no distinction between invasion, infection, and eruption. Koch's self-deception, which is what his understanding of the tuberculin reaction essentially was, resulted primarily from an unshakeable commitment to his previously developed explanatory framework. This tenacity was certainly amplified by professional competition with the Pastorians, a strongly felt need to improve his own institutional position and, finally, by seductive promises of financial profits.

A short look at the following histories of some of the developments that have been investigated in the preceding pages can further highlight the significance of the tuberculin disaster in a history of medical bacteriology.

\footnotetext{
${ }^{168}$ Little has so far been written on the history of nineteenth-century laboratory animals. Kohler makes the useful observation that they should best be seen as a special sort of domestic animal (Lords of the fly: drosophila genetics and the experimental life, University of Chicago Press, 1994, Introduction). Cf. Frederic L Holmes, 'The old martyr of science: the frog in experimental physiology', J Hist. Biol., 1993, 26: 311-28; Nicolaas Rupke (ed.), Vivisection in historical perspective, London, Croom Helm, 1987, and New York, Routledge, 1990. Klaus Amann
}

('Menschen, Mäuse und Fliegen', in M Hagner, H-J Rheinberger and B Wahrig-Schmidt (eds), Objekte, Differenzen und Konjunkturen. Experimentalsysteme im historischen Kontext, Berlin, Akademie Verlag, 1994, pp. 259-89, on p. 270) defines them as a "natural substitute" for humans. Tuberculous guinea pigs are indeed very peculiar animals: since these animals hardly ever catch the disease under normal conditions, they serve as a model for the human pathology of the disease. 


\section{Robert Koch and the Pressures of Scientific Research}

Koch had based his conception of a cure on a previously acquired understanding of a disease. It seems that with the failure of that cure the whole conception of tuberculosis centred on the pathogen started to slip. This can be shown in minor details, such as when Koch's critics from Pettenkofer's school in Munich managed to produce his tuberculin reaction by the means of extracts of entirely different bacteria. ${ }^{169}$ In addition to this, we find, immediately after the tuberculin scandal, a whole set of fundamental critiques of Koch's bacteriology. Some critics, such as Heinrich Lahmann, criticized it as illustrating the hypocrisies of scientific medicine. ${ }^{170}$ Others, more surprisingly, accused Koch's bacteriology of mysticism. Bacterial reductionism, which had been regarded as the peak of scientific medicine in the early 1880s, was now censured for its ontological conception of disease, which appeared to be non-scientific. ${ }^{171}$ The tuberculin story seems to indicate the beginning of a debate on constitution, disposition and related issues that came to occupy medicine in the 1890 s. ${ }^{172}$

What is striking is that Koch completely stepped out of these debates and continued (along with quite a number of his contemporaries) to keep his faith in tuberculin as a cure for tuberculosis. Although the tuberculin disaster probably did a lot to discredit the concept of infectious diseases as bacterial invasion, there is no indication that Koch himself realized this erosion of his work. As has been mentioned above, Koch kept on working on the issue and remained faithful to his remedy right into the twentieth century.

Finally something can be said about the constraints of Koch's bacteriology. ${ }^{173} \mathrm{His}$ knowledge of bacteria, even though it was certainly vast, was limited by a predominant interest in explaining and, indeed, fighting diseases. To call it "medical science" thus indicates both its contents and its characteristic problem. The most notable example for this is Koch's dilatory treatment of bacterial physiology. Prior to tuberculin, his knowledge was more or less confined to the need to identify, stain, nurture, and kill

\footnotetext{
${ }^{169}$ Hans Buchner, 'Tuberculinreaction durch Proteine nicht spezifischer Bacterien', Münch. Med. Wochenschr., 1891, 39: 841-3. Cf. Bulloch, op. cit., note 37 above, p. 258. An introduction to the work of Buchner and others can be found in Mazumdar, op. cit., note 91 above.

${ }^{170}$ Heinrich Lahmann, Koch und die Kochianer. Eine Kritik der Koch'schen Entdeckung und der Koch'schen Richtung in der Heilkunde, Stuttgart, Zimmer, 1890.

${ }^{171}$ Ferdinand Hueppe, 'Ueber Erforschung der Krankheitsursachen und sich daraus ergebende Gesichtspunkte für Behandlung und Heilung von Infektionskrankheiten', Berl. klinische

Wochenschr., 1891, 28: 279-83, 305-10, 333-6;

Ottomar Rosenbach, Grundlagen, Aufgaben und Grenzen der Therapie: nebst einem Anhange: Kritik des Koch'schen Verfahrens, Vienna, Urban und Schwarzenberg, 1891.

${ }^{172}$ On this debate, see Engelhardt, op. cit., note 108 above; Andrew Mendelsohn, 'The body between infection and disease: heredity, etiology,
}

and constitution in European scientific medicine, 1890-1940', in J-P Gaudellière and I Löwy (eds), Transmissions: human pathologies between heredity and infection, Amsterdam, Harwood Academic Publishers, in press.

${ }^{173}$ The notion of medical constraints has been developed by a number of authors in the last years: Olga Amsterdamska, 'Medical and biological contraints: early research on variation in biology', Soc. Stud. Sci., 1987, 17: 657-87; Ton van Helvoort, 'Bacteriological and physiological research styles in the early controversy on the nature of the bacteriophage phenomenon', Med. Hist., 1992, 26: 243-70; idem, 'A bacteriological paradigm in influenza research in the first half of the twentieth century', Hist. Philos. Life Sci., 1993, 15: 3-21. Both authors have done so in order to explain early virological research, Robert Kohler ('Bacterial physiology: the medical context', Bull. Hist. Med., 1985, 59: 54-74) has employed the concept for the early history of bacterial physiology. 


\section{Christoph Gradmann}

bacteria. Even though Koch was critical of clinical medicine and gained his knowledge not at the bedside, but by working "on the parasite itself in pure cultures", ${ }^{174}$ he undeniably had a therapeutic drive in his work. With the failure of tuberculin, questions about the components of the substance were soon put forward as ones of bacterial physiology, namely of bacterial proteins. ${ }^{175} \mathrm{~A}$ large number of researchers working on the chemical components thereby followed questions of bacterial physiology. A prominent biologist like Oscar Hertwig put forward his own theory of a physiological explanation of the tuberculin reaction in $1891 .{ }^{176}$ Work on tuberculosis bacteria demanded increasingly more expertise in chemistry and biology than before 1890.

${ }^{174}$ Koch, 'Über bakteriologische Forschung', op. cit., note 121 above, pp. 659.

${ }^{175} \mathrm{Cf}$. Hueppe, op. cit., note 171 above, who gives an overview of contemporary research on bacterial proteins.
${ }^{176}$ Oskar Hertwig, Ueber die physiologische Grundlage der Tuberculinwirkung. Eine Theorie der Wirkungsweise bacillärer Stoffwechselprodukte, Jena, Gustav Fischer, 1891. 